\title{
Comparative morphology of antennal surface structures in pleurostict scarab beetles (Coleoptera)
}

\author{
Claudia Bohacz $^{1} \cdot$ James du G. Harrison ${ }^{2} \cdot$ Dirk Ahrens $^{1} \mathbb{C}$
}

Received: 11 October 2019 / Revised: 30 May 2020 / Accepted: 16 June 2020 / Published online: 28 June 2020

(c) The Author(s) 2020

\begin{abstract}
The diverse pleurostict (phytophagous) scarab beetles with characteristically clubbed antennae exhibit striking morphological variation and a variety of different antennal sensilla. Here we compare the morphology of the antennal surface between major pleurostict lineages, including Cetoniinae, Dynastinae, Melolonthinae, Rutelinae, and a few outgroups, including Scarabaeinae and Hybosoridae. We identified various types of antennal sensilla morphologically and searched for phylogenetic patterns of sensilla within the Scarabaeidae. Sensilla were examined using SEM micrographs of 36 species and the occurrence of the different types of antennal sensilla was studied for each species. We observed a high diversity of sensilla, including multiple transitional forms. There were also a number of other interesting structures on the antennal surface with adaptive value, such as elongate elevations, serial bags, and fields of setae. Our results confirm earlier findings that within pleurostict scarabs there has occurred a clear differentiation of sensilla composition and patterns.
\end{abstract}

Keywords Scarabaeidae $\cdot$ Antennal morphology $\cdot$ Sensilla $\cdot$ Chemical communication $\cdot$ Evolution $\cdot$ SEM

\section{Introduction}

Pleurostict scarabs (Scarabaeidae) is one of the most diverse phytophagous beetle groups comprising about 25,000 species (Scholtz and Grebennikov 2005). Together with stag and dung beetles and a number of smaller groups they belong to the superfamily Scarabaeoidea, a group characterized by a club-like, pectinate antenna. Generalist plantfeeding species of the subfamilies Melolonthinae, Rutelinae, Dynastinae can be crop, pasture, and forestry pests (Jackson and Klein 2006), while others (scarabaeine and aphodiine dung beetles) are beneficial (Brussaard and Hijdra 1986). For the evolution of scarab beetles, the sequential rise of angiosperms and mammals during the Mesozoic was crucial

Electronic supplementary material The online version of this article (https://doi.org/10.1007/s00435-020-00495-0) contains supplementary material, which is available to authorized users.

Dirk Ahrens

ahrens.dirk_col@gmx.de

1 Zoological Research Museum A. Koenig Bonn, Adenauerallee 160, 53113 Bonn, Germany

2 School of Animal, Plant and Environmental Sciences, University of the Witwatersrand, Johannesburg, South Africa
(Ahrens et al. 2014): The explosive rise of angiosperms and mammals led to a radiation of coprophagous and phytophagous scarab beetles. Their morphological development over millions of years resulted in divergence in body shape, size, and extremities which provided evidence of past evolutionary pressures (Eberle et al. 2014). As finding food and conspecifics for reproduction is vital for their evolutionary success (expressed by the patterns of diversification and of morphospace), we expect similar trends in the evolution of chemical communication, i.e., expressed in the morphology and functionality of antennal sensilla. Since the evolution of chemical communication and sensilla in scarab beetles is not yet understood, it seems worthwhile to resume the study of their comparative morphology. With reference to Meinecke's (1975) early study, this study examines present structures on the antennal lamellae of pleurostict scarab beetles and related outgroup lineages, for example, dung beetles and hybosorids.

\section{Morphology and function of scarab antenna}

Chemical communication influences the antennal morphology of insects through selection pressures (Elgar et al. 2018). As in all insects, the antennae of scarab beetles are the primary sensory structures (Chapman 1998) and 
originate from the second segment of the head. The scarab antenna is generally composed of ten segments (antennomeres) being subdivided into scape, pedicel, flagellar segments (flagellum), and (usually three) lamellae (Krikken 1984). It is free to be moved in any direction by elevator and depressor muscles that are inserted into the scape. In addition, there are flexor and extensor muscles which arise in the scape and are inserted into the pedicel (Imms 1939; Chapman 1998).

The distal three antennal segments are generally leaflike, broadened; they form a fan-shaped antennal club. Theses antennal lamellae are unilaterally enlarged compared to other beetle families. Within Scarabaeidae, there is a high diversity of different shapes and characteristics in the composition of antennae (Meinecke 1975). Apart from the scape and the pedicel, the antenna cannot be moved by muscles (Meinecke 1975); the antennal lamellae are spread only by hemolymph pressure. The number of antennal lamellae (between 3 and 8) may differ between lineages, species, and sex (Honomichl 1998). Particularly, in herbivore pleurostict scarabs, the number of leaf-like widened antennomeres can be increased from 4 to 7 (Ahrens and Vogler 2008), while the total number of segments remains constant.

Scarab beetles have many sensory organs dispersed on their entire body surface, but particularly on their antennae (Romero-López et al. 2013). Among those sensory organs, both the antennal mechanoreceptors and olfactory receptors play an important role in orientation and perception and are therefore crucial for the further survival of scarab beetle. The antennal mechanoreceptors that are the precursors of sensilla are among other things crucial for proprioception and necessary for surface discrimination (Pringle 1938; Scheiner et al. 2005). In addition, some olfactory receptors in beetles can be located on the mouthpart palpi, but most of them are situated on the antennae (Crowson 1981; Seada and Hamza 2018). The olfactory sense of beetles also comprises the perception of humidity and carbon dioxide concentration (Eilers et al. 2012; Jones 2013). A high density of olfactory receptors on the antennal surface of scarab beetles may result in lower thresholds (concentrations) for the detection of food or reproductive odors which enables even the perception of these from a distant source (Dethier and Chadwick 1948; Backhaus 2001). Odorant signals can be detected from conspecifics (Nikonov et al. 2002), chemical signals from microbial processes and secondary plant metabolites (de Bruyne and Baker 2008). Therefore, the number of sensilla, surface area, and number of antennal lamellae are crucial for their functionality. Of interest, chemosensory capacities are as highly developed in pleurostict larvae as in adults (e.g., Melolontha melolontha; Eilers et al. 2012).

\section{Morphogenesis, morphology, function, and classification of sensilla}

Insect sensilla are small sensory organs and consist mainly of cuticular parts, sensory neurons, and enveloping cells (Zacharuk 1980). Differential mitosis from an epidermal sensillum mother cell leads to the development of the necessary cells for the formation of a sensilla (Keil 1997). Sensilla are primarily classified by their cuticular structures that allow them to be roughly subdivided into: sensilla trichodea (Snodgrass 1926), sensilla chaetica, sensilla basiconica, sensilla campaniformia (Moran et al. 1971), sensilla coeloconica, sensilla auricilica, sensilla placodea (Schenk 1902), and sensilla styloconica (Ryan 2002). Meinecke (1975) further divided sensilla into three main groups and two single types depending on their outer shape and their innervation visible in histological sections. Thereafter, Altner and Prillinger (1980) established a classification for hair-shaped sensilla by adding parameter-like pores and flexibility of the stand (peduncle). Nevertheless, the shape and especially the surface structure in all sensilla show a large variability and are crucial for stimulus uptake (Altner and Prillinger 1980).

Most studies of scarab antennal sensilla are based on the images from scanning electron microscopes (SEM), rarely from transmission electron microscopes (TEM) and covered by only one or a narrow selection of species (Table 1). Only Meinecke (1975) studied a wider range of scarab taxa and his results were subsequently used in phylogenetic analyses (Browne and Scholtz 1999). Here we expand the sampling to include additional systematically important groups of pleurostict scarabs (previously unstudied), and those representing early pleurostict lineages (after Ahrens et al. 2014) and summarize to this point the knowledge of the comparative morphology of scarabaeoid antennae (Fig. 1).

\section{Materials and methods}

\section{Sampling, preparation of antenna, and scanning electron microscopy}

In total, 36 species and 35 genera were analyzed (Table 2). We included all major lineages of pleurostict Scarabaeidae and a few outgroup taxa such as dung beetles (Scarabaeinae, Aphodiinae), stag beetles (Lucanidae), and Hybosoridae. The species used in this study originated from and are deposited in the collections of the Zoological Museum Alexander Koenig (ZFMK).

The lamellae were prepared for SEM following Bozzola and Russell (1999). The specimens were separately 
Table 1 Taxa considered in the previous studies on antennal club sensilla

\begin{tabular}{|c|c|}
\hline Species & References \\
\hline \multicolumn{2}{|l|}{ Cetoniinae } \\
\hline Cetonia aurata & Meinecke (1975) \\
\hline Cotinis nitida & Baker and Monroe (2005) \\
\hline Epicometis hirta & Meinecke (1975) \\
\hline Gnorimus nobilis & Meinecke (1975) \\
\hline Leucocelis elegans & Meinecke (1975) \\
\hline Mausoleopsis amabilis & Meinecke (1975) \\
\hline Osmoderma eremita & Zauli et al. $(2016 a, b)$ \\
\hline Oxythyrea funesta & Meinecke (1975) \\
\hline Pachnoda ephippia & Meinecke (1975) \\
\hline Pachnoda marginata & Bengtsson et al. (2011) \\
\hline Pachnoda interrupta & Bengtsson et al. (2011) \\
\hline Potosia affinis & Meinecke (1975) \\
\hline Potosia cuprea & Meinecke (1975) \\
\hline Potosia morio & Meinecke (1975) \\
\hline Trichius fasciatus & Meinecke (1975) \\
\hline Valgus hemipterus & Meinecke (1975) \\
\hline \multicolumn{2}{|l|}{ Dynastinae } \\
\hline Adoryphorus couloni & McQuillan and Semmens (1990) \\
\hline Oyclocephala melanocephala & Rodrigues et al. (2019) \\
\hline Oryctes nasicornis & Meinecke (1975), Renou et al. (1998) \\
\hline Phyllognathus excavatus & Meinecke (1975) \\
\hline Temnorrhynchus coronatus & Meinecke (1975) \\
\hline \multicolumn{2}{|l|}{ Melolonthinae } \\
\hline Amphimallon solistae & Meinecke (1975) \\
\hline Antitrogus parvulus & Allsopp (1990) \\
\hline Lepidiota mansueta & Sreedevi and Kumar (2018) \\
\hline Lepidiota negatoria & Allsopp (1990) \\
\hline Dasylepida ishigakiensis & Tanaka et al. (2006) \\
\hline Geotrupes auratus & Inouchi et al. (1987) \\
\hline Hoplia farinosa & Meinecke (1975) \\
\hline Hoplia sp. & Romero-López et al. (2013) \\
\hline Macrodactylus mexicanus & Romero-López et al. (2017) \\
\hline Macrodactylus nigripes & Romero-López et al. (2017) \\
\hline Maladera orientalis & Shao et al. (2019) \\
\hline Melolontha melolonta & Eilers et al. (2012) \\
\hline Pegylis sommeri & Hlalele et al. (2016) \\
\hline Phyllophaga obsoleta & Romero-López et al. (2004) \\
\hline Phyllophaga ravida & Romero-López et al. 2010 \\
\hline Phyllophaga anxia & Ochieng et al. (2002) \\
\hline Rhizotrogus maculicollis & Meinecke (1975) \\
\hline Schizonycha affinis & Hlalele et al. (2016) \\
\hline Serica brunnea & Meinecke (1975) \\
\hline \multicolumn{2}{|l|}{ Rutelinae } \\
\hline Anomala dubia & Meinecke (1975) \\
\hline Anomala corpulenta & Yao et al. (2004) \\
\hline Anomala cuprea & Leal and Mochizuki (1993) \\
\hline Anomala inconstans & Rodrigues et al. (2019) \\
\hline Anomala lanigera & Meinecke (1975) \\
\hline
\end{tabular}

Table 1 (continued)

\begin{tabular}{ll}
\hline Species & References \\
\hline Anomala praetendinosa & Meinecke (1975) \\
$\begin{array}{l}\text { Hylamorpha elegans } \\
\text { Phyllopherta horticola }\end{array}$ & Mutis et al. (2014) \\
Popillia japonica & Kim and Leal (2000) \\
Proagopertha lucidula & Lu and Wang (2009) \\
Aphodiinae & \\
Aphodius proctus & Meinecke (1975) \\
Geotrupidae & \\
Bolbelasmus gallicus & Meinecke (1975) \\
Geotrupes sylvaticus & Meinecke (1975) \\
$\begin{array}{l}\text { Geotrupes auratus } \\
\text { Lucanidae }\end{array}$ & Inouchi et al. (1987) \\
Dorcus parallelopipedus & Meinecke (1975) \\
Sinodendron cylindricum & Meinecke (1975) \\
Passalidae & \\
Popilius disjunctus & Slifer and Sekhon (1964) \\
\hline
\end{tabular}

softened in warm water overnight. The following day the antennae were separated from the head with a Dumont forceps (No. 5-Inox-B). For dehydration, the separated antennal lamellae were passed through an ascending alcohol series (with ethanol solutions of 50\%, 70\%, 90\%, and $100 \%$ ). The samples remained in each ethanol solution for five minutes and were cleaned in an ultrasonic cleaner (Emmi 30; EN IOS 9001:2000). Thereafter, each antenna was placed in an acetone filled vial for three minutes, air-dried on paper, mounted on pin stubs, and coated in a Cressington sputter coater (108 auto). SEM micrographs were taken with a Zeiss Gemini (SmartSEM, V05.00.05, SEM Type: Supra 55 VP). Here the classification of sensilla is based exclusively on the external appearance revealed by the SEM micrographs and recent papers (Romero-López et al. 2013; Zauli et al. 2016a, b). In order to classify the sensilla types, the terminology of Schneider (1964) and Zacharuk (1985) was used. For a more precise differentiation between the varieties of sensilla placodea subtypes, we referred to Meinecke (1975).

\section{Results}

The species examined in this investigation were mostly males (with three-segmented antennal clubs). In addition, some antennae from female specimens were studied in order to compare the antennal morphology of both sexes. Congruent with Meinecke (1975) we found olfactory sensilla of three main groups: (1) sensilla placodea: sensilla containing a pore plate with a cone, (2) sensilla placodea: sensilla composed of a pore plate with a stand, located in a considerably 


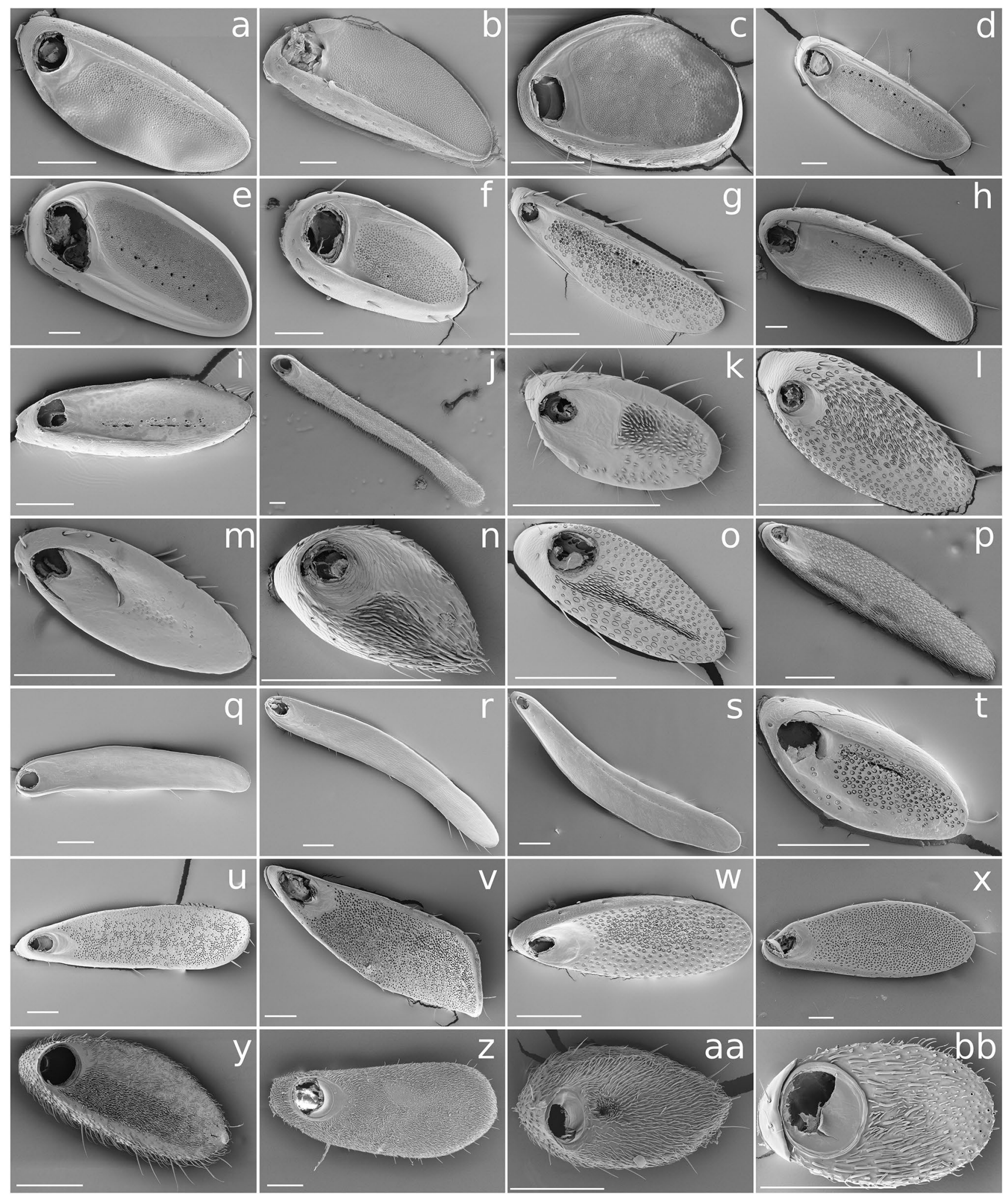

Fig. 1 Surface of the second lamella (distal view): Oxythyrea funesta $\widehat{\partial}(\mathbf{a})$; Gnorimus duodecimpunctatus $\widehat{\partial}(\mathbf{b})$; Valgus hemipterus $\widehat{\partial}(\mathbf{c})$; Cyclocephala sp. ㅇ (d); Oryctes nasicornis 9 (e); Pentodon idiota 우 (f); Proadoretus rhodesianus + ( (g); Anomala dubia $\circ$ (h); Phyllopertha horticola $\widehat{\partial}(\mathbf{i}) ;$ Xylonychus piliger $\bigcirc(\mathbf{j})$; Phyllotocus navicularis



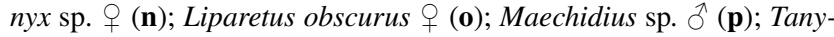
proctus sp. $\hat{\sigma}(\mathbf{q})$; Camenta innocua $\hat{\sigma}(\mathbf{r})$; Maladera holosericea $\hat{\sigma}$ (s); Hoplia philanthus $\hat{\delta}(\mathbf{t})$; Melolontha melolontha 9 (u); Amphimallon assimile $\hat{\sigma}(\mathbf{v})$; A. solstitiale $\hat{\jmath}(\mathbf{w})$; Schizonycha ruficollis + + $(\mathbf{x})$; Aphodius fossor $\widehat{\jmath}(\mathbf{y})$; Typhoeus typhoeus $\not$ ( $\mathbf{z})$; Onthophagus fracticornis (aa); Hybosorus illigeri + (bb). Scale bar $=200 \mu \mathrm{m}$ 
Table 2 List of the species examined here along with their systematic placement

\begin{tabular}{|c|c|c|c|c|c|}
\hline Species & Family & Subfamily & Tribe & Sex & No. ${ }^{\mathrm{a}}$ \\
\hline Cetonia aurata & Scarabaeidae & Cetoniinae & Cetoniini &  & 2 \\
\hline Oxythyrea funesta & Scarabaeidae & Cetoniinae & Cetoniini & $\delta^{\top}+x^{2}$ & 4 \\
\hline Trichius sp. & Scarabaeidae & Cetoniinae & Cetoniini & 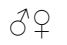 & 4 \\
\hline Osmoderma sp. & Scarabaeidae & Cetoniinae & Osmodermatini & ôto & 2 \\
\hline Gnorimus duodecimpunctatus & Scarabaeidae & Cetoniinae & Trichiini & $\delta ㅇ ㅜ$ & 4 \\
\hline Valgus hemipterus & Scarabaeidae & Cetoniinae & Valgini & $\delta^{\top}+0$ & 3 \\
\hline Cyclocephala sp. & Scarabaeidae & Dynastinae & Cyclocephalini & $\widehat{\jmath} 0+$ & 2 \\
\hline Oryctes nasicornis & Scarabaeidae & Dynastinae & Oryctini & 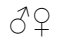 & 2 \\
\hline Pentodon idiota & Scarabaeidae & Dynastinae & Pentodontini & 우 & 2 \\
\hline Camenta inпосиа & Scarabaeidae & Melolonthinae & Ablaberini & $\hat{0}$ & 3 \\
\hline Automolus angustatus & Scarabaeidae & Melolonthinae & Automolini & $\hat{0}$ & 1 \\
\hline Diphucephala sp. & Scarabaeidae & Melolonthinae & Diphucephalini & 중 & 1 \\
\hline Heteronyx sp. & Scarabaeidae & Melolonthinae & Heteronycini & q & 2 \\
\hline Hoplia philanthus & Scarabaeidae & Melolonthinae & Hopliini & $\hat{o}$ & 2 \\
\hline Liparetus obscurus & Scarabaeidae & Melolonthinae & Liparetrini & q & 1 \\
\hline Sericoides sp. & Scarabaeidae & Melolonthinae & Liparetrini & q & 1 \\
\hline Maechidius sp. & Scarabaeidae & Melolonthinae & Maechidiini & 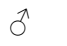 & 1 \\
\hline Melolontha melolonta & Scarabaeidae & Melolonthinae & Melolonthini & q & 4 \\
\hline Tanyproctus sp. & Scarabaeidae & Melolonthinae & Pachydemini & 0 & 1 \\
\hline Phyllotocus navicularis & Scarabaeidae & Melolonthinae & Phyllotocini & $\hat{0}$ & 1 \\
\hline Amphimallon assimile & Scarabaeidae & Melolonthinae & Rhizotrogini & $\hat{\sigma}$ & 2 \\
\hline Amphimallon solstitiale & Scarabaeidae & Melolonthinae & Rhizotrogini & $\widehat{\partial}$ & 1 \\
\hline Schizonycha ruficollis & Scarabaeidae & Melolonthinae & Schizonychini & q & 2 \\
\hline Maladera holosericea & Scarabaeidae & Melolonthinae & Sericini & $\delta ㅇ ㅜ$ & 4 \\
\hline Pleophylla navicularis & Scarabaeidae & Melolonthinae & Sericini & $\hat{\sigma}$ & 1 \\
\hline Triodontella raymondi & Scarabaeidae & Melolonthinae & Sericini & $\hat{\sigma}$ & 4 \\
\hline Xylonychus piliger & Scarabaeidae & Melolonthinae & Stethaspini & q & 1 \\
\hline Proadoretus rhodesianus & Scarabaeidae & Rutelinae & Adoretini & $\delta ㅇ+$ & 4 \\
\hline Anomala dubia & Scarabaeidae & Rutelinae & Anomalini & q & 2 \\
\hline Phyllopertha hortícola & Scarabaeidae & Rutelinae & Anomalini & $\delta^{1}$ 우 & 4 \\
\hline Aphodius fossor & Scarabaeidae & Aphodiinae & Aphodiini & $\partial^{\top}+x^{2}$ & 2 \\
\hline Onthophagus fracticornis & Scarabaeidae & Scarabaeinae & Onthophagini & q & 4 \\
\hline Typhaeus typhoeus & Geotrupidae & Geotrupinae & Typhoeini & 우 & 2 \\
\hline Hybosorus illigeri & Hybosoridae & Hybosorinae & - & 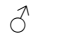 & 2 \\
\hline Sinodendron cylindricum & Lucanidae & Syndesinae & - & $\hat{0}$ & 2 \\
\hline Passalus striolatus & Passalidae & - & - & 우 & 1 \\
\hline
\end{tabular}

${ }^{\mathrm{a}}$ Number of examined specimens larger pit than group 1, and (3) cone- to hair-shaped sensilla: including sensillal trichodea (ST), sensilla basiconica (SB), sensilla coeloconica (SC), and grooved sensilla coeloconica (GSC).

Each group was partitioned into multiple subtypes (Table 3). Following Meinecke (1975) all subtypes (with their morphological characteristics) from the three main groups were recognized with the exception of st C, D, H, $\mathrm{L}, \mathrm{M}$, and $\mathrm{N}$, as these subtypes can only be clearly distinguished from the other subtypes by cross sections showing the sensory innervation, the cuticular ridges below the pore plate surface, the wall thickness and tiny pores on the sensillar surface. In addition, the subtypes elliptical sensilla (ES), sensilla auricilica (SA), leaf-shaped sensilla (LSS), and elongated sensilla placodea (ESP) were added to the classification.

The various subtypes of sensilla are listed for each species examined in Table 4 . The patterns of the distribution of the sensilla from all major lineages (i.e., tribes) examined are illustrated in Fig. 1 and described below in detail for each species studied. Meinecke (1975) included histological data (e.g., cross sections of sensilla) allowing for further subdivisions; however, this study focused on SEM micrograph data only. 
Table 3 Classification and description of sensilla with additional subtypes used in this study

\begin{tabular}{|c|c|c|c|}
\hline Group & Subtype & Description & \\
\hline \multirow[t]{6}{*}{1} & & Pore plate with a cone (sensilla placodea) & \\
\hline & A & Pit is slight larger than the sensilla itself & Figures $4 \mathrm{i}-\mathrm{q}, 5 \mathrm{u}$ \\
\hline & $\mathrm{B}$ & $\begin{array}{l}\text { Strongly flattened sensilla, transition between sensilla and pit hardly visible, sensilla almost at } \\
\text { the same height with pit }\end{array}$ & Figure $5 \mathrm{w}, \mathrm{x}$ \\
\hline & $\mathrm{E}$ & Invaginations in the pore plates & Figure $4 r-w$ \\
\hline & $\mathrm{F}$ & Bumpy, rough, folded, patelliform pore plate & Figures $4 \mathrm{x}, 5 \mathrm{a}-\mathrm{g}, \mathrm{n}, \mathrm{o}, \mathrm{s}, \mathrm{t}$, \\
\hline & $\mathrm{G}$ & Folded pore plate with cuticular swellings & Figure $5 \mathrm{~h}-\mathrm{j}$ \\
\hline \multirow[t]{7}{*}{2} & & Pore plate with a stand & \\
\hline & $\mathrm{J}$ & Pit is considerably larger than the therein located sensilla & Figure $5 \mathrm{k}, 1$ \\
\hline & $\mathrm{K}$ & Folded pore plate, raised edges (bowl shaped) & Figure $3 \mathrm{~s}, 5 \mathrm{~m}, \mathrm{p}-\mathrm{r}$ \\
\hline & ESP & Elongated sensilla placodea & Figure $6 \mathrm{~h}-1$ \\
\hline & ES & Elliptical sensilla: similar to A but elliptical-shaped, flat, or convex surface & Figures $4 c-h, 5 v$, Fig. 6a, b, g \\
\hline & SA & $\begin{array}{l}\text { Sensilla auricilica: rabbit-ear-shaped, similar to subtype K, but less folded surface than subtype } \\
\text { K, sometimes forked tip }\end{array}$ & Figures $3 \mathrm{t}-\mathrm{v}, 6 \mathrm{f}$ \\
\hline & LSS & $\begin{array}{l}\text { Leaf-shaped sensilla: folded ones similar to SA but more ovate-leaf-shaped, flat ones similar to } \\
\text { ES but more pointed tip, sometimes forked tip and larger, located in a smaller pit, flat or lifted } \\
\text { edges }\end{array}$ & Figures $2 \mathrm{p}-\mathrm{t}, 3 \mathrm{w}, \mathrm{x}, 4 \mathrm{a}, \mathrm{b}$ \\
\hline \multirow[t]{5}{*}{3} & & Cone to hair-shaped sensilla & \\
\hline & ST & Sensilla trichodea: predominantly long hair-like sensilla, pointed or blut tip,flattened & Figure $2 b, c, f-o, u$ \\
\hline & SB & Sensilla basiconica: shorter than ST, mostly blunt tip & Figures $2 \mathrm{c}-\mathrm{e}, \mathrm{h}, 3 \mathrm{e}-\mathrm{g}, 6 \mathrm{c}$ \\
\hline & $\mathrm{SC}$ & Sensilla coeloconica: peg- to cone-shaped sensilla in a shallow pit, smooth surface & Figure $3 a-d, h-r, 6 d, e$ \\
\hline & GSC & $\begin{array}{l}\text { Grooved SC: short, peg-shaped sensilla, located in a shallow pit,with pointed tip, longitudinally } \\
\text { grooved terminal and smooth basal area }\end{array}$ & Figure $2 \mathrm{v}-\mathrm{x}$ \\
\hline
\end{tabular}

\section{Cetoniinae}

The species representing the scarab subfamily Cetoniinae have a three-segmented antennal club with specialized sensilla (Scholtz and Grebennikov 2005). They exhibit mainly sensilla from group 1 (pore plate with cone) which were predominantly spread on the interior area of the antennal club. Various different types of sensilla placodea occurred in high density on the inner surface of the antennal lamellae, among them smooth, grooved, and flattened types. Each antennal lamella showed predominantly two zones. The homogenous inner zone was covered with multiple types of sensilla placodea and some isolated sensilla coeloconica and grooved sensilla coeloconica. The homogeneous outer zone was covered with strongly flattened and smooth, sensilla placodea (st B). A special feature of this group was the existence of a field of setae, which differed in size between the species and was located on the basal surface of the first lamella (Fig. S1).

Osmoderma eremita (Osmodermatini): The interior areas of the three-segmented antennal club was covered mainly with sensilla of the subtypes A, B, and only few isolated sensilla coeloconica and grooved sensilla coeloconica. A wide spectrum of sensilla diameters $(9-14 \mu \mathrm{m})$ and surface conditions were present (Figs. 2w, 4k,1, S1, S14), e.g., grooved median surface and a pore plate of sensilla placodea with a smooth margin (subtypes A and B). Subtypes with a shallow pit (st B) were predominantly present on the marginal area (Figs S1, S14, 5w, x).

Cetonia aurata (Cetoniini): The inner surface of the antennal club was covered largely with sensilla of the subtypes A and B (Figs. 2m, 3i, 4j, n, q, S1, S14). Although the flattened subtype B occurred on the edge region (see also Fig. 5w, x). The sensilla coeloconica and the grooved sensilla coeloconica are spread isolated on the inner lamellar surface of the antennal club.

Oxythyrea funesta (Cetoniini): The three-segmented antennal club comprised the sensilla subtypes A, B, and F (Figs. 1a, S2, S15). In addition, there were many isolated cuticular perforations distributed in the edge region of the antennal lamellae (Fig. S2E). Only few grooved sensilla coeloconica were present on the inner surfaces of the antennal lamella.

Trichius fasciatus (Cetoniini): contained the subtypes A and B on its antennal surface (Figs. 3p, q, S2, S15). Although the strongly flattened subtype B belonged to the most frequently present subtype on the outer and inner surface of the antennal club (Fig. $5 \mathrm{w}$ ). Short sensilla basiconica are distributed along the margins of the antennal lamellae. In addition, there were many isolated cuticular perforations distributed in the edge region of the antennal lamellae (Fig. $\mathrm{S} 2 \mathrm{H})$. 
Table 4 Presence of different subtypes of sensilla (s.) and additional morphological characteristics on the antennal lamellae of the examined species [terminology after Schneider (1964), Zacharuk (1985), and Meinecke (1975)]

$\begin{array}{llllllllllllllll}\text { A } & \text { B } & \text { E } & \text { F } & \text { G } & \text { J } & \text { K } & \text { ST } & \text { SB } & \text { SC } & \text { GSC } & \text { SA } & \text { ESP } & \text { ES } & \text { LSS } & \text { FS }\end{array}$

\section{Cetoniinae}

\begin{tabular}{|c|c|c|c|c|c|c|c|c|c|c|c|c|c|c|c|}
\hline Cetonia aurata & $\mathrm{X}$ & $\mathrm{X}$ & & & & & & $\mathrm{X}$ & $\mathrm{X}$ & $\mathrm{X}$ & $\mathrm{X}$ & & & & \\
\hline Oxythyrea funestra & $\mathrm{X}$ & $\mathrm{X}$ & & & & & & $X$ & $\mathrm{X}$ & $\mathrm{X}$ & $\mathrm{X}$ & & & & \\
\hline Osmoderma sp. & $\mathrm{X}$ & $\mathrm{X}$ & & & & & & $\mathrm{X}$ & $\mathrm{X}$ & $\mathrm{X}$ & $\mathrm{X}$ & & & & \\
\hline Trichius sp. & $\mathrm{X}$ & $\mathrm{X}$ & & & & & & $X$ & $\mathrm{X}$ & $\mathrm{X}$ & $X$ & & & & \\
\hline Gnorimus duodecimpunctatus & $\mathrm{X}$ & $\mathrm{X}$ & & & & & & $X$ & $\mathrm{X}$ & $\mathrm{X}$ & $\mathrm{X}$ & & & & \\
\hline Valgus hemipterus & $X$ & $\mathrm{X}$ & $\mathrm{X}$ & & & & & $X$ & $\mathrm{X}$ & $X$ & $X$ & & & & \\
\hline \multicolumn{16}{|l|}{ Dynastinae } \\
\hline Cyclocephala sp. & $\mathrm{X}$ & $\mathrm{X}$ & & $\mathrm{X}$ & & & & $X$ & $\mathrm{X}$ & $\mathrm{X}$ & $\mathrm{X}$ & & & & \\
\hline Oryctes nasicornis & $\mathrm{X}$ & $\mathrm{X}$ & & $\mathrm{X}$ & & & & $\mathrm{X}$ & $\mathrm{X}$ & $\mathrm{X}$ & $\mathrm{X}$ & & & & \\
\hline Pentodon idiota & $\mathrm{X}$ & $\mathrm{X}$ & & $X$ & & & & $X$ & $\mathrm{X}$ & $\mathrm{X}$ & $X$ & & & & \\
\hline \multicolumn{16}{|l|}{ Rutelinae } \\
\hline Proadoretus rhodesianus & & $\mathrm{X}$ & & & $\mathrm{X}$ & & & $X$ & $\mathrm{X}$ & $\mathrm{X}$ & $X$ & & & & \\
\hline Anomala dubia & & $\mathrm{X}$ & & & $\mathrm{X}$ & & & $\mathrm{X}$ & $\mathrm{X}$ & $\mathrm{X}$ & $\mathrm{X}$ & & & & \\
\hline Phyllopertha horticola & & $\mathrm{X}$ & & & $\mathrm{X}$ & & & $X$ & $\mathrm{X}$ & $\mathrm{X}$ & $X$ & & & & \\
\hline \multicolumn{16}{|l|}{ Melolonthinae } \\
\hline Automolus angustatus & & & & & & & $\mathrm{X}$ & $X$ & $\mathrm{X}$ & $\mathrm{X}$ & $\mathrm{X}$ & & & & $x$ \\
\hline Diphucephala sp. & & & & & & & & $X$ & $\mathrm{X}$ & $\mathrm{X}$ & $X$ & & & $\mathrm{X}$ & \\
\hline Heteronyx sp. & & & & & & & & $\mathrm{X}$ & $\mathrm{X}$ & & $\mathrm{X}$ & & & & \\
\hline Hoplia philanthus & & & & & & $\mathrm{X}$ & $\mathrm{X}$ & $\mathrm{X}$ & $\mathrm{X}$ & $\mathrm{X}$ & $\mathrm{X}$ & $\mathrm{X}$ & & & \\
\hline Liparetus obscurus & & & & & & & & $\mathrm{X}$ & $\mathrm{X}$ & $\mathrm{X}$ & $\mathrm{X}$ & & & $\mathrm{X}$ & $x$ \\
\hline Phyllotocus navicularis & & & & & & & & $\mathrm{X}$ & $\mathrm{X}$ & $\mathrm{X}$ & $\mathrm{X}$ & & & $\mathrm{X}$ & 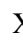 \\
\hline Sericoides sp. & & & & & & & & $X$ & $\mathrm{X}$ & & $X$ & & & & \\
\hline Maechidius sp. & & & & & & & & $\mathrm{X}$ & $\mathrm{X}$ & & $\mathrm{X}$ & & & & \\
\hline Xylonychus piliger & & & & & & & & $\mathrm{X}$ & $\mathrm{X}$ & & $\mathrm{X}$ & & & & \\
\hline Tanyproctus sp. & & & & & & & & $X$ & $\mathrm{X}$ & $\mathrm{X}$ & $X$ & & $\mathrm{X}$ & & \\
\hline Amphimallon assimile & & & & & & $\mathrm{X}$ & $\mathrm{X}$ & $X$ & $\mathrm{X}$ & $\mathrm{X}$ & $\mathrm{X}$ & $\mathrm{X}$ & & & \\
\hline Amphimallon solstitiale & & & & & & $X$ & $X$ & $X$ & $\mathrm{X}$ & $X$ & $X$ & $X$ & & & \\
\hline Melolontha melolontha & & & & & & $\mathrm{X}$ & $\mathrm{X}$ & $\mathrm{X}$ & $\mathrm{X}$ & $\mathrm{X}$ & $\mathrm{X}$ & $X$ & & & \\
\hline Schizonycha ruficollis & & & & & & & $\mathrm{X}$ & $\mathrm{X}$ & $\mathrm{X}$ & $\mathrm{X}$ & $\mathrm{X}$ & $\mathrm{X}$ & & & \\
\hline Camenta innocua & & & & & & $\mathrm{X}$ & & $\mathrm{X}$ & $\mathrm{X}$ & & $\mathrm{X}$ & & $\mathrm{X}$ & $\mathrm{X}$ & \\
\hline Maladera holosericea & & & & & & & & $X$ & $\mathrm{X}$ & & $X$ & & $\mathrm{X}$ & $\mathrm{X}$ & \\
\hline Pleophylla navicularis & & & & & & & & $\mathrm{X}$ & $\mathrm{X}$ & & $\mathrm{X}$ & & $\mathrm{X}$ & & \\
\hline Tridontella raymondi & & & & & & & & $X$ & $\mathrm{X}$ & & $X$ & & $\mathrm{X}$ & $\mathrm{X}$ & \\
\hline \multicolumn{16}{|l|}{ Aphodiinae } \\
\hline Aphodius fossor & & & & & & & & $X$ & $\mathrm{X}$ & & $X$ & & & & \\
\hline \multicolumn{16}{|l|}{ Geotrupidae } \\
\hline Typhoeus typhoeus & & & & & & & & $X$ & $\mathrm{X}$ & & $X$ & & & & \\
\hline \multicolumn{16}{|l|}{ Scarabaeinae } \\
\hline Onthophagus fracticornis & & & & & & & & $\mathrm{X}$ & $\mathrm{X}$ & & $X$ & & & & \\
\hline \multicolumn{16}{|l|}{ Hybosoridae } \\
\hline Hybosorus illigeri & & & & & & & & $X$ & $\mathrm{X}$ & & $X$ & & & & \\
\hline \multicolumn{16}{|l|}{ Lucanidae } \\
\hline Sinodendron cylindricum & & & & & & & & $X$ & $\mathrm{X}$ & & $X$ & & & & \\
\hline \multicolumn{16}{|l|}{ Passalidae } \\
\hline Passalus striolatus & & & & & & & & $\mathrm{X}$ & $\mathrm{X}$ & & $X$ & & & & \\
\hline
\end{tabular}

$S T$ sensilla Trichodea, $S B$ sensilla basiconica, SC sensilla coeloconica, GSC grooved sensilla coeloconica, $S A$ sensilla auricilica, ESP elongated sensilla placodea, $E S$ elliptical sensilla, $L S S$ leaf-shaped sensilla, $F S$ field of setae 


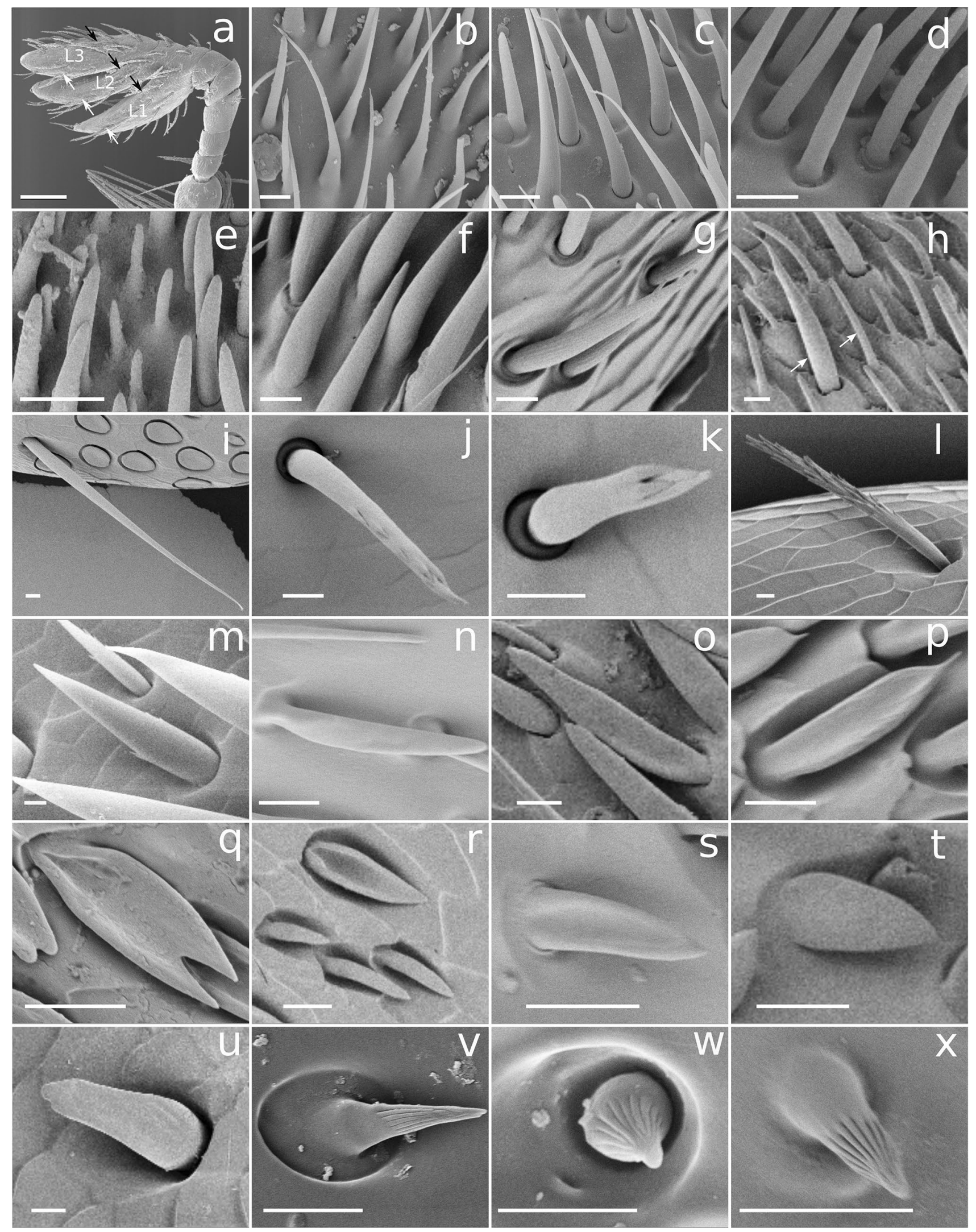


4Fig. 2 Antenna overview, with lamella (L) 1-3 a indicating the distal and basal views (black and white arrows, respectively); sensilla types: b sensilla trichodea; c sensilla basiconica (blunt tips), sensilla trichodea (longer, pointed tips); $\mathbf{d}-\mathbf{e}$ sensilla basiconica $\mathbf{f}, \mathbf{g}, \mathbf{i}$ sensilla trichodea; $\mathbf{h}$ : sensilla basiconica (white arrowhead), sensilla trichodea (black arrowhead) $\mathbf{j}-\mathbf{m}$ sensilla trichodea with a brush-like terminal; $\mathbf{n}-\mathbf{o}$ flattened sensilla trichodea; p-t leaf-shaped sensilla (st LSS); r LSS (above), flattened LSS sensilla (below); u sensilla trichodea; $\mathbf{v}-\mathbf{x}$ grooved sensilla coeloconica (GSC), cone to hair shaped with a smooth basal and a grooved terminal surface. Triodontella (a); Onthophagus (b-d); Heteronyx (e-g); Sericoides (h, o); Liparetus (i, $\mathbf{p}, \mathbf{q})$; Oryctes $(\mathbf{j}, \mathbf{k})$; Valgus $(\mathbf{l}, \mathbf{u})$; Cetonia $(\mathbf{m}) ;$ Aphodius $(\mathbf{n}) ;$ Automolus (r); Phyllotocus (s,t); Camenta (v); Osmoderma (w); Diphucephala $(\mathbf{x})$. Scale bar $=5 \mu \mathrm{m}$

Gnorimus duodecimpunctatus (Trichiini): The interior areas of the antennal club were covered mainly with sensilla A and B (Figs. 1b, 3n, 4o, 5x, S3, S16). Some isolated sensilla coeloconica were also present on the inner lamellar surfaces (Fig. 3n). The peripheral edges and the distal surface of the third lamellae were covered with isolated sensilla trichodea with a pointed apex (Fig. S3).

Valgus hemipterus (Valgini): The antennal surface was covered with the subtypes A, B, and E (Figs. 1c, 4i, p, r-w). Although the middle region of each lamella was covered with clearly smaller sensilla with deeper pits and inversions (st E). The edge region was predominantly covered with the subtypes A and B (Figs. S3, S16). Only few sensilla coeloconica and grooved sensilla coeloconica were distributed on the inner surface of the antennal lamellae. The third lamella from distal view showed isolated smooth sensilla trichodea and sensilla trichodea with a brush-like surface (Figs. 2l, S3I, S16L). Whereas the first antennal lamella exhibited besides isolated sensilla trichodea a field of seta consisting of thicker but shorter sensilla trichodea with a blunt tip (Figs. 2u, S3J, S16G).

\section{Rutelinae}

The three-segmented antennal club of Rutelinae is predominantly covered by sensilla of the first group. Thus, different subtypes of sensilla placodea (sts A and B) were particularly present on the inner surface of the antennal club, but in this subfamily sensilla placodea were also numerously present on the distal surface of the third lamellae. In addition, some isolated sensilla coeloconica and grooved sensilla coeloconica were present in all studied specimens (see also Figs. 2v-x, 3a-d, h-r, 6d, e). Characteristic for this subfamily was the existence of rounded and elongate bags or even furrows (Figs. S13, S24) on the hidden, inner surface of the lamellae and long, massive sensilla trichodea with a pointed apex on the distal side of the third lamella.

Proadoretus rhodesianus (Adoretini): The scale-like outer lamellar surface was covered mainly with sensilla from the subtypes G and B (Figs. 1g, 5h, S13). The sensilla of subtype $\mathrm{G}$ occurred particularly densely in or in proximity to the multiple bags on the inner surface of the antennal club (Fig. S13B). However, the subtype B sensilla were located predominantly on the edge regions (Fig. S13F).

Anomala dubia (Anomalini): The three-segmented antennal club exhibited a scale-like outer surface of the lamella and a smooth inner surface (Figs. 1h, S24). The surface of the antennal lamellae had sensilla of the subtypes $G$ and B. Some subtypes had a characteristic tortoise shell-like surface which was made of polygonal plates (Fig. 5j).

Phyllopertha horticola (Anomalini): The inner surface of the three-segmented antennal club was mainly covered with sensilla of the subtypes B and G (Figs. 1i, 5i, S13, $\mathrm{S} 25)$. Conspicuous was that some subtype $\mathrm{G}$ sensilla were perforated. Multiple bags, arranged in a row, were present on the inner surface of the antennal club. Multiple variants of subtype $\mathrm{G}$ were situated mainly in or in proximity to the bags. Although density of sharply pointed and thick sensilla trichodea was the highest on the basal side of the first lamella (Fig. S13J), the distal side of the third lamellae was partly covered with strongly flattened sensilla placodea (st B).

\section{Dynastinae}

The Dynastinae, whose species usually have small threesegmented antennal clubs (Scholtz and Grebennikov 2005), had mainly sensilla placodea from the first group, sensilla coeloconica and the grooved sensilla coeloconica. Some representatives of the Dynastinae also tend to exhibit a field of seta on the basal surface of the first antenna lamella. However, this tendency is less pronounced and the distribution of sensilla trichodea within the fields of the seta is more irregular. All representatives from this subfamily exhibited a variety of bags on the inner surface of their lamellae (Fig. 1d-f). In addition, single sensilla basiconica and sensilla trichodea, sometimes varying greatly in size, were distributed around the peripheral edges of each lamella (Fig. S4).

Cyclocephala sp. (Cyclocephalini): is characterized by a considerable diversity of transitional forms of the subtypes A, B, and F (Figs. 1d, 5b, c, t, u). Although the pore plate was mostly folded irregularly. The antennal lamellae indicated two zones: a heterogeneous zone and a smooth area (Fig. 1d). In the heterogeneous zone, a few different types of sensilla (predominantly subtypes A, F, and some isolated sensilla coeloconica) were present. The smooth area contained strongly flattened sensilla placodea of the subtype $\mathrm{B}$, which were situated in pits that were hardly noticeable. Particularly, conspicuous was the high number of small and rounded bags (from 14 to 21) which contained sensilla and were arranged in a row on both sides of each lamella, aside from the basal side of the first lamella (Figs. S17). On the 





४Fig. 3 Sensilla types: $\mathbf{a}-\mathbf{d}, \mathbf{h}-\mathbf{r}$ various sensilla coeloconica; $\mathbf{s}$ thrombocyte-shaped sensilla (st K); e-g: sensilla basiconica; $\mathbf{t}-\mathbf{v}$ sensilla auricilica (st SA) w, x: different variations of leaf-shaped sensilla (st LSS). Melolontha (a, h, o, s); Heteronyx (b); Tanyproctus (c); Diphucephala (d); Camenta (e); Maladera (f); Phyllotocus (g); Cetonia (i); Oryctes (j,m); Pentodon (k, r); Amphimallon (l); Gnorimus (n); Trichius (p, q); Schizonycha (t, v); Hoplia (u); Liparetus (w); Automolus $(\mathbf{x})$. Scale bar $=5 \mu \mathrm{m}$

basal surface of the first lamella and the distal surface of the third lamella, various sensilla trichodea were visible, including the brush-like sensilla trichodea (see also Figs. 2j, k, S4).

Oryctes nasicornis (Oryctini): The inner surface of the antennal club was mainly covered with sensilla of the subtypes A, B, and F (Figs. 1e, 3j, m, 4m, 5a, d-g, s). Multiple bags ( $>20$ on one surface) mainly arranged in two rows, were present on the inner surface of the antennal lamellae (Fig. S4G, H, L). Isolated sensilla trichodea, including brush-like sensilla trichodea were present on the outer surface of the antennal club (Figs. 2j, k, S4J).

Pentodon idiota (Pentodontini): Subtypes A, B, and F were visible on the inner surface of lamellae (Figs. 1f, 3k, r, $4 x, 5 n, o, S 18)$. The surface of the antennal lamellae showed a heterogeneous area in the middle and a smooth area around the edges. The heterogeneous area was covered mostly with sensilla of the subtype F. However, the smaller smooth area was covered only with the strongly flattened subtype B sensilla, excluding several short, sensilla basiconica distributed along the edges (See also Fig. 5w, x). Several small rounded bags covered with sensilla were positioned in one row on the distal side of the first and second lamella and on the basal side of the third lamellae (Fig. S18B-E).

\section{Melolonthinae}

The antennal club of Melolonthinae is composed of three to eight sometimes extremely elongated and tightly folding antennal lamellae (Scholtz and Grebennikov 2005). Although the smooth antennal surface was covered mainly with sensilla from the second group and isolated sensilla coeloconica, grooved sensilla coeloconica, sensilla basiconica, sensilla trichodea. Further sensilla types, not listed in Meinecke's (1975) classification (see below) were also present. In addition, the antennal surface from some representatives showed elongated elevations which we classified as elongated sensilla placodea (ESP) (Fig. 6h-l).

Camenta innocua (Ablaberini): The elongated antennal club is in male composed of seven lamellae, it had very few short sensilla basiconica (Fig. 3e). The whole surface of the antennal club was covered with slender and long elongated sensilla placodea (Fig. 6k, 1, S5). Most of the elliptical sensilla and sensilla coeloconica present were arranged in a loosely aggregated row. The basal surface of the lamellae was nearly free of sensilla, excluding some randomly distributed short, sensilla basiconica, grooved sensilla coeloconica, and several elliptical sensilla. Besides their shape, elliptic sensilla were situated in a small pit, some were strongly flattened and others had a more convex surface (Figs. 1r, 2v, 3e, 4d, f, 5v, 6b, g). On the distal surface of the last lamella several ellipse-shaped sensilla were visible. In addition, all peripheral edges of the antennal lamellae were covered with isolated, enlarged sensilla trichodea.

Automolus angustatus (Automolini): The lamellae exhibited predominantly sensilla with an ovate leaf shape which were classified as leaf-shaped sensilla (Figs. 11, 2r, 3x, 4b, S6). Flattened leaf-shaped sensilla were distributed on the basal surface and on the border areas of the lamella. A high density of curved leaf-shaped sensilla was situated in the middle of the distal surface of the three lamellae. In comparison to the distribution of sensilla on the outer surface of the antennal club, the sensilla on the inner surface were larger, more curved and occurred more frequently.

Diphucephala sp. (Diphucephalini): The three-segmented club exhibited sensilla especially on the distal surface of the three lamellae (Figs. 1m, 2x, 3d, S6, S19). Several different transitional forms of elliptical sensilla, sensilla coeloconica and grooved sensilla coeloconica, were present on the antennal lamellae (Figs. 3d 4c, e, g, 6a). Within the three lamellae, the second lamellae showed the lowest density of sensilla.

Heteronyx sp. (Heteronycini): The three-segmented antennal club had a scale-like surface structure (Fig. S19). Except from the lamella tip, where sensilla trichodea and sensilla basiconica were located, the basal sides of the lamellae were covered only with a few sensilla (Figs. 1n, 2e-g, $3 b)$. Sensilla trichodea and sensilla basiconica were present on the peripheral edges of the lamellae and occurred predominantly on the distal surface of the three lamellae. The grooved sensilla coeloconica were also present on the distal lamellae.

Hoplia philanthus (Hopliini): The scale-like surface of the three-segmented antennal club contained the sensilla subtypes J, K, and sensilla auricilica (Figs. 1t, 3u, 5m, S7). The surface of all lamellae exhibited the above-mentioned sensilla, but in different densities, the inner surfaces of the antennal club showed more sensilla. Some sensilla trichodea were located on the peripheral edges, on the basal side of the first lamellae and on the distal side of the third lamellae. The subtype $\mathrm{K}$ and sensilla auricilica occurred predominantly in the middle of the distal surface of the lamellae (Figs. 3u, $5 \mathrm{~m})$. There are also frequently dispersed on the basal sides of the second and third lamella. The subtype J was distributed predominantly on the edge regions.

Liparetus obscurus (Liparetrini): had multiple sensilla coeloconica and grooved sensilla coeloconica (Figs. 1o, 2i, p, q, 3w, 4a). All of them were cone-shaped and situated in larger pits. However, there were also elongated, leafshaped sensilla (Fig. 2p, q). Most sensilla were leaf shaped 


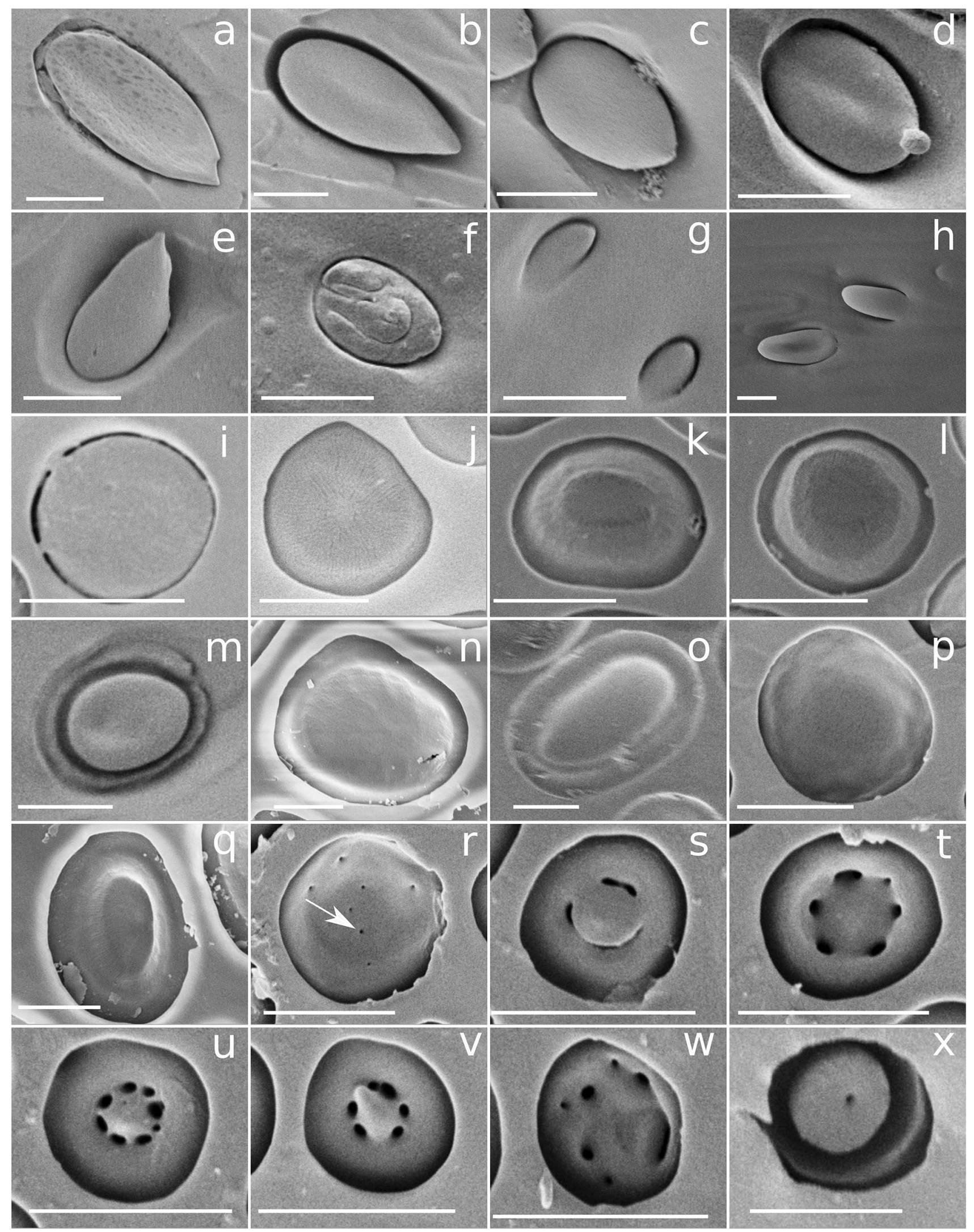


४Fig. 4 Sensilla types: a, b leaf-shaped sensilla (st LSS) c-h ellipticalshaped sensilla (st ES); e elliptical sensilla, with a gently pointed; i-p different variations of sensilla placodea (st A); $\mathbf{k}-\mathbf{n}$ pore plate softly bent outwards (st A); o-q sensilla placodea, pore plate softly bent inwards (st $\mathrm{A}$ ); $\mathbf{r}-\mathbf{w}$ transitional forms of st $\mathrm{E}$ with inversions in the pore plate; $\mathbf{x}$ sensilla with single inversion in the pore plate (st F). Liparetus (a); Automolus (b), Diphucephala (c, e, g); Camenta (d, f); Triodontella $(\mathbf{h})$; Valgus $(\mathbf{i}, \mathbf{p}, \mathbf{r}-\mathbf{w}) ;$ Cetonia $(\mathbf{j}, \mathbf{n}, \mathbf{q}) ;$ Osmoderma $(\mathbf{k}$, l); Oryctes (m); Gnorimus (o); Pentodon (x); Scale bar $=5 \mu \mathrm{m}$

or elliptical and some were even slightly curved; they were distributed on the basal side and on the distal side of the lamellae (Fig. S20). Each lamella contained one elongated furrow on the basal and distal surface. The furrows on the distal surface of the first and second lamella are wider and longer than those on the basal surface. The strongly elongated leaf-shaped sensilla were concentrated in the furrows (Fig. 2q). The distal side of the third lamellae even contained two furrows. In addition, isolated sensilla trichodea were present on the distal side of the third lamella and the lateral edges of each lamella (Fig. 2i).

Sericoides sp. (Liparetrini): The antennal lamellae had slight and elongated sensilla trichodea, with a pointed apex. Some of these were flattened (Fig. 2o). Sensilla were present predominantly on the marginal region and the outer lamellar surface (Fig. S20). Smaller sensilla basiconica with a rounded apex are distributed on the distal and on the basal surface (Fig. 2h, o). Although, the density of sensilla is lower on the basal surface of the lamellae. In addition, very few grooved sensilla coeloconica were distributed on the distal surfaces of the antennal lamellae.

Maechidius sp. (Maechidiini): had an elongated, threesegmented antennal club which is covered with uniform sensilla basiconica (Figs. 1p, S7). The sensilla basiconica had a rounded apex and were inserted into a peak of a cuticular scale-like structure. The outer surface showed denser coverage with sensilla due to additional sensilla trichodea with a larger cross section and a pointed apex.

Melolontha melolontha (Melolonthini): The elongated antennal club showed a grooved, scale-like surface covered with sensilla coeloconica, grooved sensilla coeloconica, auricilic sensilla and the subtypes J, K (Figs. 1u, 3a, h, o, s, $5 \mathrm{k}, \mathrm{q}, \mathrm{r}, 6 \mathrm{~d}, \mathrm{f}, \mathrm{S} 21)$. The male antennal club was extremely enlarged and composed of eight lamellae, whereas the female antennal club consisted of only six lamellae. Some isolated sensilla trichodea, situated in large pits, were distributed on the peripheral edges of the antennal lamellae and on the distal surface of the last lamellae.

Tanyproctus sp. (Pachydemini): The antennal club was composed of seven antennomeres and exhibited smooth surface structure (Fig. S8). The lamellar surface only had a small amount of sensilla. The distal surface of the lamellae had the highest density of sensilla. Besides the grooved sensilla coeloconica, there were sensilla present that were classified as elongated sensilla placodea (Figs. 1q, 3c, $6 \mathrm{~h}-\mathrm{j})$.

Phyllotocus navicularis (Phyllotocini): The three-segmented antennal club is much smaller than the antennal club of most species from the Melolonthinae subfamily (Figs. 1k, 2s, t, 3g, 5v, S9). Beside sensilla basiconica, the lamellae contained different types of sensilla which did not fit clearly in any main groups defined by Meinecke (1975). Therefore, these sensilla were classified as leaf-shaped sensilla (Fig. 2s, t). The basal surface of the first lamella, the distal surface of the third lamellae, and all peripheral edges of the lamellae, contained isolated sensilla trichodea with a pointed apex. Additional few elliptical sensilla were distributed mainly along the edges of the distal surface of the lamellae (Fig. 5v).

Amphimallon assimile (Rhizotrogini): exhibited the subtypes J, K, and sensilla auricilica (Figs. 1v, 31, 5l, p, S9). These were predominantly found evenly distributed on the inner surface of the antennal club. Isolated sensilla trichodea were visible on the outer surface of the antennal club. The basal side of the first lamellae is covered only with a few sensilla from the subtype J. The aforementioned sensilla occurred on particularly the distal parts of the lamellae.

Amphimallon solstitiale (Rhizotrogini): The subtypes $\mathrm{J}$ and $\mathrm{K}$ occurred on the surface of the antennal lamellae (Fig. S10), distribution of the sensilla was very similar to the previous species.

Schizonycha ruficollis (Schizonychini): The three-segmented antennal club exhibited a tortoise shell-shaped outer surface (Figs. 1x, 3t, v, 6c, S22). The inner surface was scale like and slightly grooved. The subtype $\mathrm{K}$ and sensilla auricilica were mostly located in the middle of the lamellae. Sensilla were mostly on the inner surface of the antennal club. Only a few sensilla trichodea were present on the outer surface of the antennal club.

Maladera holosericea (Sericini): The three-segmented antennal club showed a very smooth surface. In contrast to the females, the male antennal club was heavily elongated and thinner (Figs. 1s, 3f, S10, S22). In addition, the sensilla from males are arranged in a row on an elongated pit. Only a few mostly isolated sensilla were present on the lamellar surface. Sensilla trichodea with a sharp apex were distributed on the peripheral edges of the antennal lamellae. Most sensilla were situated on the distal surface of the lamellae. Short sensilla basiconica with a rounded apex, and elliptical and elongated sensilla placodea were visible on the antennal lamellae (see also Fig. 6k, 1).

Pleophylla navicularis (Sericini): The elongated, fivesegmented antennal club exhibited a smooth surface and had many softly curved elevations, which look like elongated sensilla placodea (Fig. S11). The small amounts of sensilla were distributed mainly on the distal lamella (1-4). Among them, there were also elliptical sensilla (Fig. 5v). 


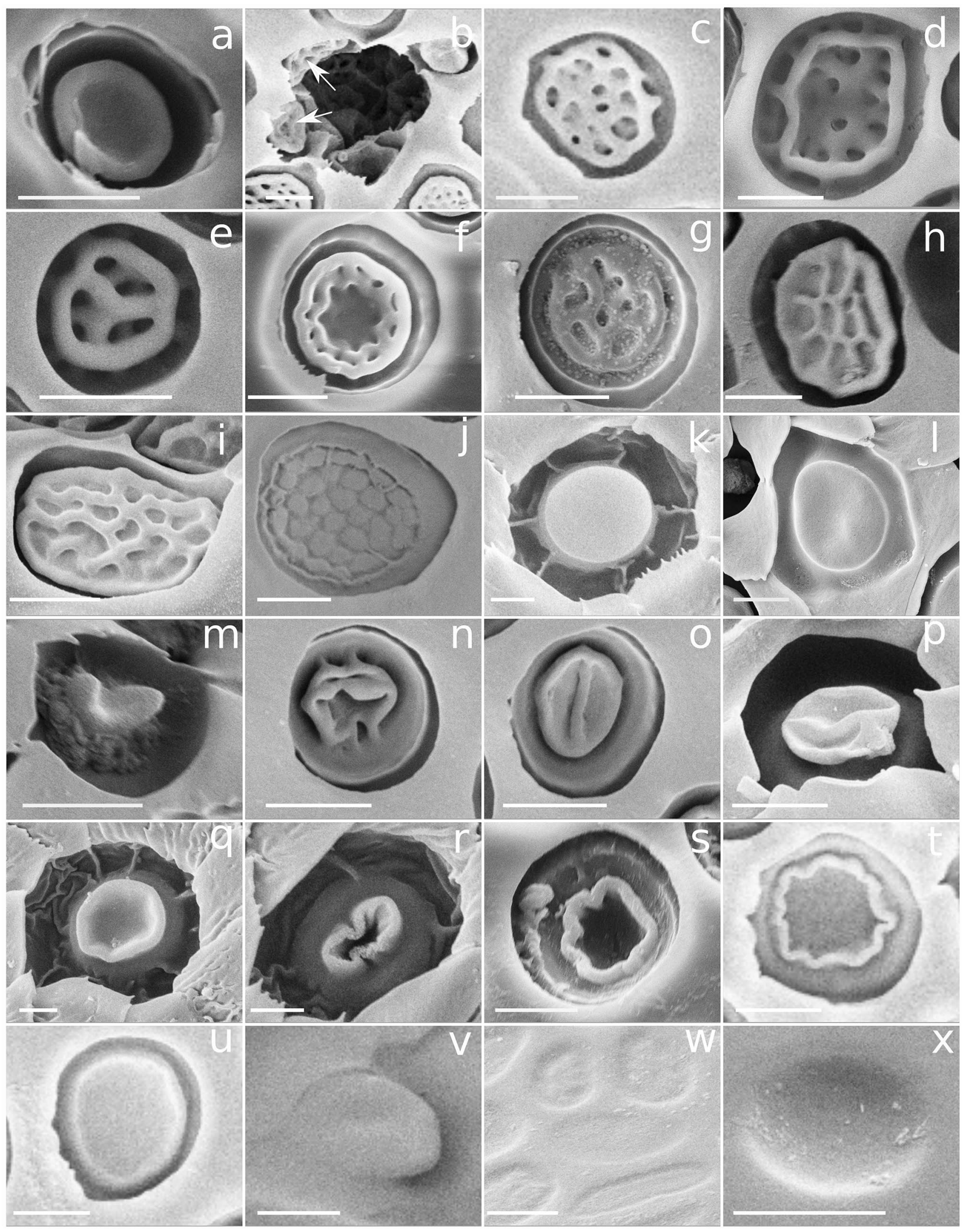


४Fig. 5 Sensilla types: a sensilla placodea with reflexed pore plate edge, subtype (st) F; b bag opening with sensilla placodea st F; $\mathbf{c}-\mathbf{g}$ sensilla placodea st $\mathbf{F} ; \mathbf{h}-\mathbf{j}$ different transitional shapes of st $\mathrm{G} ; \mathbf{k}, \mathbf{l}$ sensilla placodea st J; $\mathbf{m}$ sensilla st $\mathrm{K}$; $\mathbf{n}-\mathbf{o}$ placoid sensilla with irregularly folded pore plate; st F; p-r sensilla with a bowl-shape pore plate (st K); s, t sensilla placodea with irregularly folded edges (st F); $\mathbf{u}$ sensilla placodea (st A); $\mathbf{v}$ elliptical sensilla; $\mathbf{w}, \mathbf{x}$ flattened sensilla placodea (st B). Oryctes (a, d-g, s); Cyclocephala (b, c, t, u); Proadoretus (h); Phyllopertha sp. (i); Anomala (j); Melolontha (k, q, r); Amphimallon assimile (l, p); Hoplia $(\mathbf{m})$; Pentodon (n, o); Phyllotocus $(\mathbf{v})$; Trichius $(\mathbf{w})$; Gnorimus $(\mathbf{x})$. Scale bar $=5 \mu \mathrm{m}$

Triodontella raymondi (Sericini): The smooth, threesegmented antennal club was poorly covered with sensilla (Figs. 2a, 4h, 6k, 1, S12), except for some grooved sensilla coeloconica, elliptical sensilla, and few isolated sensilla trichodea distributed on the outer surface of the antennal club (Figs S13, 6k, 1). In particular, elongated sensilla were spread on all surfaces of the antennal lamella.

Xylonychus piliger (Stethaspini): The antennal lamellae are extremely elongated and predominantly covered with sensilla trichodea (Figs. 1j, S23). Furthermore, all sensilla trichodea had a slightly curved tip and were inserted into a massive stand. Only a few sensilla basiconica and sensilla coeloconica were sporadically present without a conspicuous distribution pattern on the surfaces of the antenna lamellae (Fig. S23).

\section{Aphodiinae}

Aphodius fossor (Aphodiini): The three lamellae from each antenna were extensively covered with sensilla trichodea (Fig. 1y). The majority of these are flattened sensilla trichodea (Fig. 2n). On the outer surface of the antennal club there were mostly sensilla trichodea which are thicker, longer and more sharply pointed than the sensilla on the protected inner surface of the lamellae (Figs. S26, S29). The distal side of the third lamella had an elongated notch with basiconic sensilla situated inside of it. Also, isolated grooved sensilla coeloconica were present mainly on the distal surfaces of the three lamellae (Fig. 2v-x).

\section{Scarabaeinae}

Onthophagus fracticornis (Onthophagini): The three-segmented antennal club was largely covered with different sensilla basiconica and sensilla trichodea (Figs. 1aa, 2b-d, S27). Among these different types, there were straight, sensilla basiconica, in particular situated in a large and deep pore on the distal surface of the first and second lamella (Fig. 2d). Furthermore, sensilla trichodea with a pointed tip and shorter sensilla basiconica were distributed heterogeneously on the remaining lamellar surface as well as several isolated large sensilla trichodea on the distal surface of the third lamella and the peripheral edges of each lamella.

\section{Geotrupidae}

Typhaeus typhoeus (Typhoeini): The surface of the three-segmented antennal club was densely covered with fine, sensilla trichodea (Fig. S31). Although, the majority of the sensilla trichodea on the distal surface of the first and second lamella were short and blunt tipped, the sensilla on the basal surface were thicker and had a pointed tip.

\section{Hybosoridae}

Hybosorus illigeri (Hybosorinae): The three-segmented antennal club was mostly covered with flattened, sensilla trichodea (Figs. 1bb, S28). The distal surface of the half a coconutshaped third lamellae was the place where different flattened sensilla trichodea occurred in their highest density. Besides, flattened sensilla trichodea, there were also larger and thicker sensilla trichodea with a large cuticular elevation. Grooved sensilla coeloconica were only distributed sporadically on the distal surfaces of all antennal lamellae.

\section{Lucanidae}

Sinodendron cylindricum (Syndesinae): The three-segmented, more pectinate antennal club mainly exhibited sensilla basiconica (Fig. S29). The outer surface had a smooth, scaly structure, which apart from a few sensilla trichodea and sensilla basiconica, is free of sensilla. Various types of sensilla basiconica in different sizes were visible on the distal surface of each lamella (Fig. S29D, E). In particular, a high number of predominantly short, sensilla basiconica occurred on the distal surface of the third lamellae (Fig. S29F). In addition, the distal surfaces of the first and second lamella were curved inwards.

\section{Passalidae}

Passalus striolatus (Passalinae): The sensilla situated on the surface of the three-segmented antennal club of Passalidae were all slender sensilla trichodea and sensilla basiconica and occurred in a high density (Fig. S32). The peripheral edges and some basal surfaces (first and second lamella) were covered with isolated and thick sensilla trichoidea of which some were curved and extremely elongated.

\section{Discussion}

Within Pleurosticts, and namely in their major lineages (e.g., Cetoniinae, Dynastinae, Melolonthinae, and Rutelinae), in comparison to the examined scarabaeoid outgroup 


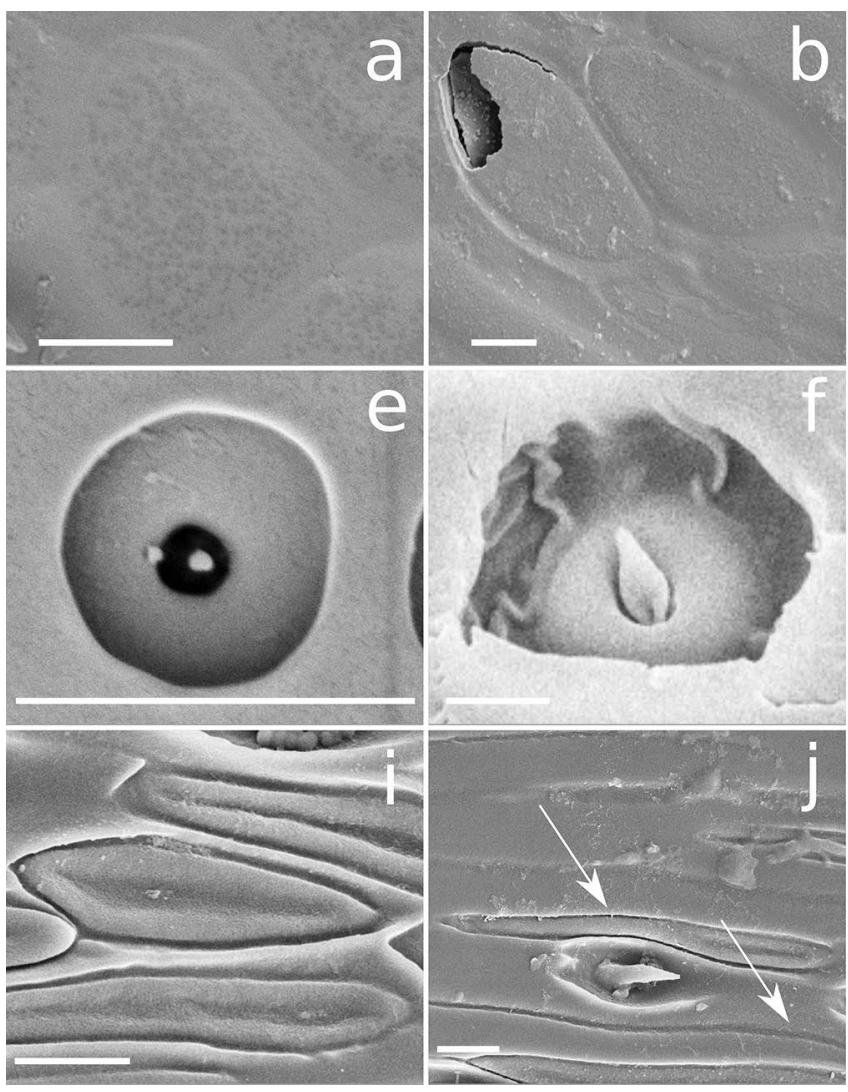

Fig. 6 Sensilla types: a, b, $\mathbf{g}$ elliptical sensilla; $\mathbf{c}$ sensilla basiconica located in a shallow pit; $\mathbf{d}$, e sensilla coeloconica; $\mathbf{f}$ sensilla auricilica h-l elongate sensilla. Diphucephala (a); Camenta (b, g); Schizonycha

taxa (Aphodiinae, Scarabaeinae, Geotrupidae, Lucanidae, Hybosoridae, and Passalidae) there seem to be recognizable clear trends in the presence and distribution of antennal sensilla.

Representatives of Cetoniinae, Rutelinae, and Dynastinae, which form a monophyletic group (e.g., Ahrens et al. 2014; McKenna et al. 2019), have predominantly pore plate sensilla. Although subtypes A and B and showed here the highest frequency, while representatives of Rutelinae exhibiting mainly the subtypes $\mathrm{G}$ and $\mathrm{B}$ (Table 4).

Sensilla patterns within the species of Melolonthinae examined were not uniform: they have mainly sensilla of the second group (pore plate with a stand) while a few species even have sensilla of the third group (Tables 3 and 4). Sensilla trichodea, sensilla basiconica, and sensilla coeloconica were generally present in all studied species. Some sensilla, whose type was not described by Meinecke (1975), occurred additionally in the southern world melolonthines, such as Automolus angustatus, Liparetus obscurus, Phyllotocus navicularis, in Tanyproctini (Tanyproctus sp.), Ablaberini (Camenta innocua), and Sericini (Maladera holosericea, Pleophylla navicularis and Triodontella raymondi). Besides elongated sensilla, also a high diversity of

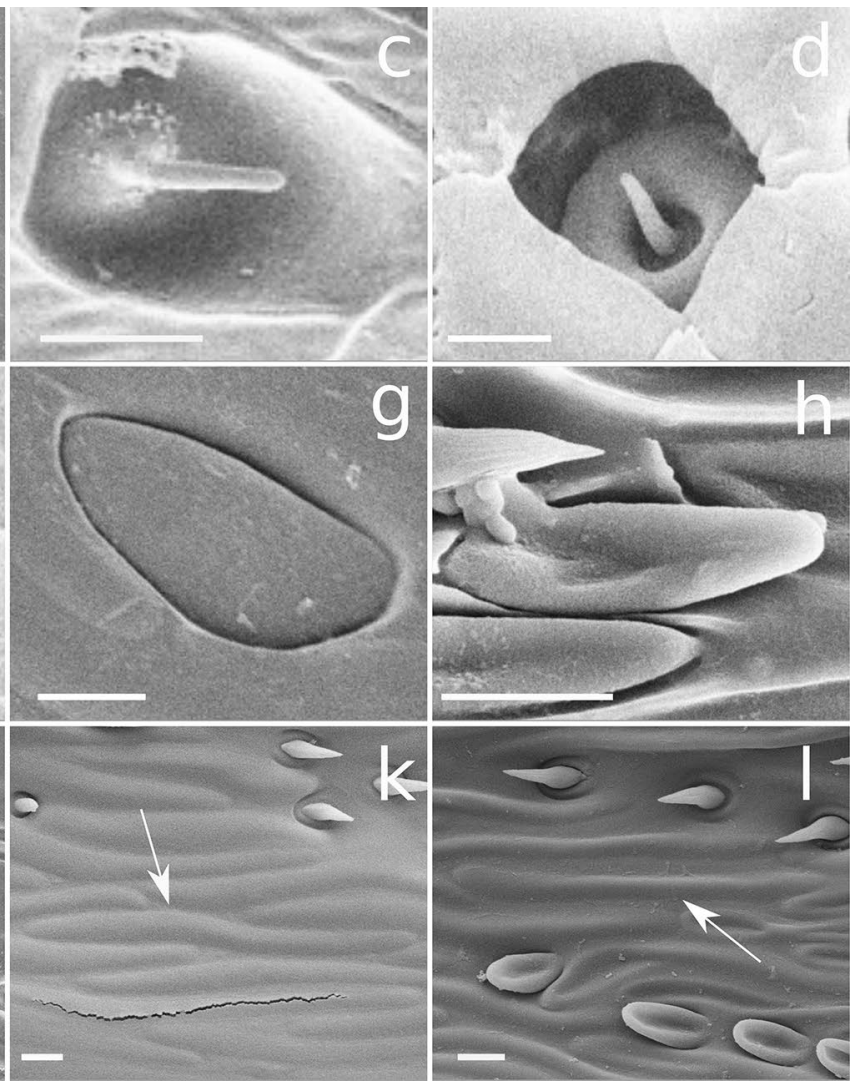

(c); Melolontha $(\mathbf{d}, \mathbf{f}) ;$ Valgus $(\mathbf{e}) ;$ Tanyproctus $(\mathbf{h}-\mathbf{j}) ;$ Triodontella $(\mathbf{k}$ l). Scale bar $=5 \mu \mathrm{m}$

leaf-shaped sensilla occurred in Phyllotocus, Liparetus and Automolus (Fig. 2p-r). Whereas different transitional subtypes of elliptical-shaped sensilla were present on the antennal lamella of Diphucephala sp., Camenta innocua, Phyllotocus navicularis and Triodontella raymondi (Figs. 4c-h, $5 \mathrm{v}, 6 \mathrm{a}, \mathrm{b}, \mathrm{g})$.

The most striking deviation of sensilla morphology, i.e., extremely elongated sensilla placodea, we encountered in Tanyproctini, Ablaberini, and Sericini (Fig. 6b, g, i-l). In particular within Sericini (Maladera holosericea, Pleophylla navicularis and Triodontella raymondi) these exhibited a high density on the lamella. Therefore, their recognition as sensilla of sensilla placodea subtype, which are in all other cases round, is somewhat controversial. However, in contrast to $P$. navicularis and $T$. raymondi, the appearance and external delimitation of these elongated sensilla placodea was less distinct in Maladera holosericea. These examined elongated sensilla placodea were also found on the antennal surface of Tanyproctus sp. However, in contrast to the elongated sensilla placodea of the Sericini, in which transition between sensilla and pit was not clearly evident from the SEM images (Fig. 6k, 1), the elongated sensilla of Tanyproctus were generally shorter and situated in a larger pit (Fig. 6h, i, j). It can 
be excluded that these cuticular elevations which we classified as elongate sensilla are only microsculptures, since this would mean that Sericini do not have at all a considerable number of olfactory sensilla despite they clear tendency of antennal surface augmentation (Ahrens and Vogler 2008).

The strong divergence among different sensilla patterns within Melolonthinae including presence or absence of certain important antennal sensilla types reflects in some kind the non-monophyly of the Melolonthinae (Coca-Abia 2007). Since Melolonthinae have been found to be a nonmonophyletic group (Ahrens and Vogler, 2008; Ahrens et al. 2014; Eberle et al. 2019; McKenna et al. 2019), it is quite likely that differences in the occurrence and distribution of sensilla in some tribes are a confirmation of the divergent phylogenetic relationships and provide useful evidence to infer the evolution of the Melolonthinae, but also of all pleurostict scarabs, with particular reference to their chemical communication.

All here examined outgroups lineages (in relation to the pleurostict scarabs), i.e., Aphodius fossor (Aphodiinae), Onthophagus fracticornis (Scarabaeinae), Typhoeus typhoeus (Geotrupidae), Hybosorus illigeri (Hybosoridae), Sinodendron cylindricum (Lucanidae), and Passalus striolatus (Passalidae), exhibited almost exclusively sensilla trichodea and sensilla basiconica sensilla. The highest density of sensilla trichodea and sensilla basiconica occurred in dung-feeding Aphodius fossor, Typhoeus typhoeus, and Onthophagus fracticornis. Furthermore, Passalus had long sensilla trichodea with a curved tip. Hybosorus illigeri even showed modified (slightly flattened) sensilla trichodea.

The presence of a setal field on the basal (external) surface of the first lamella in the subfamilies Cetoniinae and Dynastinae, is one peculiarity, and leaves space to some considerations on the function of those setae-fields. In particular, because it appears that those field have originated independently from each other, and that in most other cases olfactory sensilla are all situated on the inside of the lamellae. If they were found only in Cetoniinae, one could speculate that they could have arisen due to selective pressures in the context of their pollen feeding and flower pollination. However, certain Dynastinae are not known to feed on pollen.

Additionally so far unreported structures include the multiple bags on the interior lamellar surface which are covered with sensilla. If present, they were situated predominantly on the distal surface of the first and second lamellae (Rutelinae). In contrast to the bags found in Cetoniinae and Dynastinae, bags of Rutelinae are larger, shallower and more irregularly shaped. Trichius fasciatus and Gnorimus duodecimpunctatus (both Cetoniinae) showed only a few isolated bags, mainly distributed on the distal surface of their first lamella. The functional role of bags is still uncertain. It could be that they contributing to a better (i.e., vortexed) air circulation for the purpose of olfaction.

In all these cases, as well as in that on the distal part of the second lamella of Onthophagus, we may definitely exclude that the bags or pores are artifacts. All cases show a smooth transition at edge into the pores/ bags, with often visible sensilla also inside the deepening (at walls and bottom). The pore of Onthophagus is by far larger in diameter compared to the bags in the other lineages (Fig. 1aa).

We could not find evidence for a clear differentiation of sensilla types between males and females for those taxa where both sexes were examined. However, both sexes are known to differ in many scarab lineages in the size and number of antennal lamellae (e.g., Ahrens and Vogler 2008; Mutis et al. 2014) and also in the number of sensilla per lamella (e.g., Allsopp 1990; Tanaka et al. 2006; RomeroLópez et al. 2010; Mutis et al. 2014).

The fact that chemical communication causes selection pressures which influences the antennal morphology and may therefore be crucial for the morphology and evolution of antennal sensilla would seem to be obvious (Elgar et al. 2018). Consequently, phylogentic patterns of sensilla evolution are to be expected also in relation to the lifestyle of the species. Our results confirmed widely the findings of Meinecke (1975): each lineage has multiple subtypes of sensilla on the inner surface of the antennal club, but only from one type of main group (pore plate with cone vs. pore plate with stand vs. cone- to hair-shaped sensilla: including sensilla trichodea, sensilla basiconica, sensilla coeloconica and grooved sensilla coeloconia). Many subtypes that Meinecke has described could be proven (Table 4). Unfortunately, due to the lack of cross sections some placoid subtypes and the hair-like sensilla from Meinecke's third group were excluded or adapted to common standard terminology for sensilla (Table 3).

Additionally, similar to the findings of a few previous papers (e.g., Bengtsson et al. 2011, Romero-López et al. 2013 , 2017) that examined congeneric taxa, all species from one genus, e.g., Amphimallon assimile and Amphinallon solstitiale displayed the same subtypes and could not be distinguished (intraspecifically) by the comparison of the distribution of sensilla. In contrast, differences between male and female within genera, particularly in the number of sensilla apart from the size (length) of the antennal lamella (e.g., Tanaka et al. 2006; Romero-López et al. 2010), are widely known and were also confirmed here (although not principally addressed in this study), but not for all groups studied (e.g., Sericini and dung beetles).

In particular, some taxa (e.g., Liparetus obscurus, Schizonycha and Tanyproctus) exhibited additional further sensilla type, which was not described by Meincke (1975) nor any other authors: e.g., elongated sensilla placodea (Fig. 6k,l). Similar features were also found by Gao et al. (2007) who 
examined the antennal morphology of Microplitis pallidipes (Hymenoptera: Braconidae). This wasp species showed also elongated sensilla placodea, which were similar but more homogenous compared to that of Tanyproctus sp. (Fig. 6h-j).

Romero-López et al. (2013) examined distribution of sensilla on the antennae of 24 species of Hopliini. Their results are in line with our findings confirming that Hopliini usually have various subtypes of the sensilla placodea, sensilla coeloconica, sensilla auricilica and sensilla basiconica. Here we revealed also some similarities in the occurrence of leaf-shaped sensilla (as a special case of sensilla trichodea) in some southern world Melolonthinae (e.g., Automolus, Liparetrus, Phyllotocus) with those of the southern African hopliine Pachynema squamosa. Romero-López et al. (2013) classified a very similar sensillum (from Pachynema squamosa) as a sensilla auricilica (type II) and described it as a small rabbit-ear-shaped structure which tends to be elliptical and low dome shaped.

Investigations of Leal and Mochizuki (1993) regarding the enantiomeric discrimination by sensilla placodea in Anomala cuprea (Rutelinae) confirmed that just one prominent sensilla subtype [case subtype G (Fig. 5c-j)] occurs in Rutelinae. This subtype occurred frequently in Anomala cuprea and Anomala dubia. Similar sensilla were also present on the antennal surface of Phyllopherta horticola (Rutelinae). Kim and Leal (2000) studied the ultrastructure of the pheromone-sensitive sensillum placodeum which due to its tortoise-like surface is very similar to some sensilla on the antennal surface of Anomala dubia and Phyllopertha horticola, and may therefore be related to some flat subtypes G (Fig. 5i, j).

It was conspicuous that elongated sensilla placodea were found also on the antennal surface of the Sericini species and a Tanyproctus sp. (Tanyproctini). However, this finding was not unexpected as all species with elongated sensilla placodea were representatives of Melolonthinae sensu lato. Nevertheless, the findings for the representatives of the subfamily Melolonthinae are notable since most male specimens have enlarged fan-shaped lamellae and we therefore expected a higher density of sensilla thereon, which was not always the case (Figs. 21, 24, 27, 28).

Given the presence of sensilla trichodea in all scarab lineages, it is likely that these functions mainly as mechanoreceptors and as mechanical protection (e.g., against water saturation). Compared with scarab beetles, antenna of other Arthropoda like the crustaceans contain more mechanosensory and enveloping cells than insects (Hallberg et al. 1997). The representatives of Crustacea frequently exhibit different types of tubular-shaped sensilla (Derby and Weissburg 2014). Nevertheless, the question whether all sensilla in beetles/insects have the same origin, i.e., derived from a non-scolopale hair-shaped sensillum or a scolopidial sensillum is unresolved, but for additional discussion of this topic please refer to (Hallberg and Hansson 1999). However, these questions, especially the relations of homology between the different expressions of sensilla types are crucial for the understanding of the evolution of sensilla and chemical communication. Given, that we found in many of the studied species also different intermediate states between different sensilla subtypes, makes the task no easier. One could argue, that histological examination would enhance the understanding of homology between different sensilla. However, the histological sections depicted in Meinecke (1975) leave little room for better data resolution via histology as its variation is increased by another order of magnitude. Especially chemosensory sensilla, which are distinguished most effectively by electrophysiological tests and the analysis of their chemosensory responses (Frazier and Hanson 1986), have been investigated in many insect species, but in very few scarab species (e.g., Bengtsson et al. 2011; Lu and Wang 2009).

Finally, one question would also be whether different types of sensilla "smell" the same odors (i.e., substances), or whether different sensilla smell different things? This would provide a further basis for a deeper understanding and to give meaning to the variation of the shape and the density/distribution of sensilla observed. Thus, far there is evidence that one sensillum type may smell different odors (Sun et al. 2014), thus the question seems to be a complex one.

Another issue to address would be a more robust phylogenetic reconstruction of the ancestral types of sensilla for the pleurostict scarabs. This would allow us to infer general trends of sensilla evolution in context of a phylogenetic tree and to deduce patterns of evolution and convergence with the different scarab lineages. This would, however, require a more detailed sampling of non pleurostict Scarabaeiformia.

Acknowledgements Open Access funding provided by Projekt DEAL. We thank Jonas Eberle for his help and support of this study in many ways, Karin Ulmen for her help in the use of the ZFMK scanning electron microscope, Jana Speer and Benedict Wipfler for their advice regarding sample preparation. We also thank Wolfgang Wägele for his advice on an earlier draft of the manuscript.

\section{Compliance with ethical standards}

Conflict of interest Claudia Bohacz declares that she has no conflict of interest. James du G. Harrison declares that he has no conflict of interest. Dirk Ahrens declares that he has no conflict of interest.

Ethical approval This article does not contain any studies with human participants or living animals performed by any of the authors.

Open Access This article is licensed under a Creative Commons Attribution 4.0 International License, which permits use, sharing, adaptation, distribution and reproduction in any medium or format, as long 
as you give appropriate credit to the original author(s) and the source, provide a link to the Creative Commons licence, and indicate if changes were made. The images or other third party material in this article are included in the article's Creative Commons licence, unless indicated otherwise in a credit line to the material. If material is not included in the article's Creative Commons licence and your intended use is not permitted by statutory regulation or exceeds the permitted use, you will need to obtain permission directly from the copyright holder. To view a copy of this licence, visit http://creativecommons.org/licenses/by/4.0/.

\section{References}

Ågren L (1985) Architecture of a lamellicorn flagellum (Phyllopertha horticola, Scarabaeidae, Coleoptera, Insecta). J Morphol 186:85-94

Ahrens D, Vogler AP (2008) Towards the phylogeny of chafers (Sericini): analysis of alignment-variable sequences and the evolution of segment numbers in the antennal club. Mol Phylogenet Evol 47:783-798

Ahrens D, Schwarzer J, Vogler AP (2014) The evolution of scarab beetles tracks the sequential rise of angiosperms and mammals. Proc R Soc B 281:20141470

Allsopp P (1990) Sexual dimorphism in the adult antennae of Antitrogus parvulus Britton and Lepidiota negatoria Blackburn (Coleoptera: Scarabaeidae: Melolonthinae). Austr Entomol 29:261-266

Altner H, Prillinger L (1980) Ultrastructure of invertebrate chemo-, thermo-, and hygroreceptors and its functional significance. Int Rev Cytol 67:69139

Backhaus W (ed) (2001) Neuronal coding of perceptual systems. World Scientific, Singapore

Baker GT, Monroe WA (2005) Sensilla on the adult and larval antennae of Cotinis nitida (Coleoptera: Scarabaeidae). Microsc Microanal 11(S02):170

Bengtsson JM, Khbaish H, Reinecke A, Wolde-Hawariat Y, Negash M, Seyoum E (2011) Conserved, highly specialized olfactory receptor neurons for food compounds in 2 congeneric scarab beetles, Pachnoda interrupta and Pachnoda marginata. Chem Senses 36:499-513

Bozzola JJ, Russell LD (1999) Electron microscopy: principles and techniques for biologists. Jones \& Bartlett Learning, Burlington

Browne J, Scholtz CH (1999) A phylogeny of the families of Scarabaeoidea (Coleoptera). Syst Entomol 24(1):51-84

Brussaard L, Hijdra RD (1986) Some effects of scarab beetles in sandy soils of the Netherlands. Geoderma 37:325-330

Chapman RF (1998) The insects: structure and function, 4th edn. Cambridge University Press, Cambridge

Coca-Abia MM (2007) Phylogenetic relationships of the subfamily Melolonthinae (Coleoptera, Scarabaeidae). Insect Syst Evol 38:447-472

Crowson RA (1981) The biology of the Coleoptera. Academic Press, London

De Bruyne M, Baker TC (2008) Odor detection in insects: volatile codes. J Chem Ecol 34:882-897

Derby CD, Weissburg MJ (2014) The chemical senses and chemosensory ecology of crustaceans. Nat Hist Crustacea 3:263-292

Dethier VG, Chadwick LE (1948) Chemoreception in insects. Physiol Rev 28:220-254

Eberle J, Myburgh R, Ahrens D (2014) The evolution of morphospace in phytophagous scarab chafers: no competition-no divergence? PLoS ONE 9(5):e98536

Eberle J, Sabatinelli G, Cillo D, Bazzato E, Šípek P, Sehnal R, Bezděk A, Král D, Ahrens D (2019) A molecular phylogeny of Melolonthinae chafer beetles revisits the polyphyly of Tanyproctini (Coleoptera, Scarabaeidae). Zool Scr 48:349-358

Eilers EJ, Talarico G, Hansson BS, Hilker M, Reinecke A (2012) Sensing the underground-ultrastructure and function of sensory organs in root-feeding Melolontha melolontha (Coleoptera: Scarabaeinae) larvae. PLoS ONE 7(7):e41357

Elgar MA, Zhang D, Wang Q, Wittwer B, Thi Pham H, Johnson TL, Freelance CB, Coquilleau M (2018) Insect antennal morphology: the evolution of diverse solutions to odorant perception. Yale J Biol Med 91(4):457-469

Frazier JL, Hanson FE (1986) Electrophysiological recording and analysis of insect chemosensory responses. In: Miller JR, Miller TA (eds) Insect-plant interactions. Springer series in experimental entomology. Springer, New York, pp 285-330

Gao Y, Luo LZ, Hammond A (2007) Antennal morphology, structure and sensilla distribution in Microplitis pallidipes (Hymenoptera: Braconidae). Micron 38:684-693

Hallberg E, Hansson BS (1999) Arthropod sensilla: morphology and phylogenetic considerations. Microsc Res Technol 47:428-439

Hallberg E, Johansson KU, Wallén R (1997) Olfactory sensilla in crustaceans: morphology, sexual dimorphism, and distribution patterns. Int J Insect Morphol Embryol 26:173-180

Hlalele MA, Shuttleworth A, Conlong D (2016) Detection of host plant volatiles in melolonthid beetles, Pegylis sommeri and Schizonycha affinis (Coleoptera: Scarabaeidae). S Afr J Bot 103:317

Honomichl K (1998) Biologie und Ökologie der Insekten/ein Taschenlexikon; begr. von Jacobs, W. \& Renner, M., 3rd edn. Gustav Fischer Verlag, Stuttgart

Imms AD (1939) On the antennal musculature in insects and other arthropods. J Cell Sci 81:273-320

Inouchi J, Shibuya T, Matsuzaki O, Hatanaka T (1987) Distribution and fine structure of antennal olfactory sensilla in Japanese dung beetles, Geotrupes auratus Mots. (Coleoptera: Geotrupidae) and Copris pecuarius Lew. (Coleoptera: Scarabaeidae). Int J Insect Morphol Embryol 16:177-187

Jackson TA, Klein MG (2006) Scarabs as pests: a continuing problem. Col Bull 60:102-119

Jones W (2013) Olfactory carbon dioxide detection by insects and other animals. Mol Cells 35(2):87-92

Keil TA (1997) Comparative morphogenesis of sensilla: a review. Int J Insect Morphol Embryol 26:151-160

Kim JY, Leal WS (2000) Ultrastructure of pheromone-detecting sensillum placodeum of the Japanese beetle, Popillia japonica Newmann (Coleoptera: Scarabaeidae). Arthr Struct Dev 29:121-128

Krikken J (1984) A new key to the suprageneric taxa in the beetle family Cetoniidae, with annotated lists of the known genera. Zool Verh 210:1-75

Leal WS, Mochizuki E (1993) Sex pheromone reception in the scarab beetle Anomala cuprea Enantiomeric discrimination by sensilla placodea. Naturwiss 80:278-281

Lu CK, Wang XQ (2009) Ultrastructure of olfactory sensilla on the antenna of Proagopertha lucidula (Coleoptera: Scarabaeidae). Act Entomol Sin 52:39-45

McKenna DD, Shin S, Ahrens D, Balke M, Beza C, Clarke DJ, Donath A, Escalona HE, Friedrich F, Letsch H, Liu S, Maddison D, Mayer C, Misof B, Murin PJ, Niehuis O, Peters RS, Podsiadlowski L, Pohl H, Scully ED, Yan EV, Zhou X, Ślipiński A, Beutel RG (2019) The evolution and genomic basis of beetle diversity. PNAS 116(49):24729-24737

McQuillan PB, Semmens TD (1990) Morphology of antenna and mouthparts of adult Adoryphorus couloni (Burmeister) (Coleoptera: Scarabaeidae: Dynastinae). Aust J Entomol 29:75-79

Meinecke CC (1975) Riechsensillen und Systematik der Lamellicornia (Insecta, Coleoptera). Zoomorphology 82:1-42 
Moran DT, Chapman KM, Ellis RA (1971) The fine structure of cockroach campaniform sensilla. J Cell Biol 48:155-173

Mutis A, Palma R, Parra L, Alvear M, Isaacs R, Morón M, Quiroz A (2014) Morphology and distribution of sensilla on the antennae of Hylamorpha elegans Burmeister (Coleoptera: Scarabaeidae). Neotrop Entomol 43:260-265

Nikonov AA, Peng G, Tsurupa G, Leal WS (2002) Unisex pheromone detectors and pheromone-binding proteins in scarab beetles. Chem Sens 27:495-504

Ochieng SA, Robbins PS, Roelofs WL, Baker TC (2002) Sex pheromone reception in the scarab beetle Phyllophaga anxia (Coleoptera: Scarabaeidae). Ann Entomol Soc Am 95:97-102

Pringle JWS (1938) Proprioception in insects: III. The function of the hair sensilla at the joints. J Exp Biol 15:467-473

Renou M, Tauban D, Morin JP (1998) Structure and function of antennal pore plate sensilla of Oryctes rhinoceros (L.) (Coleoptera: Dynastidae). Int J Insect Morphol Embryol 27:227-233

Rodrigues SR, Fuhrmann J, Amaro RA (2019) Aspects of mating behavior and antennal sensilla in Anomala inconstans Burmeister, 1844 (Coleoptera: Scarabaeidae: Rutelinae). Biota Neotropica 19(3):e20180664. https://doi. org/10.1590/1676-0611-BN-2018-0664

Romero-López AA, Arzuffi R, Valdez J (2004) Sensory organs in the antennae of Phyllophaga obsoleta (Coleoptera: Melolonthidae). Ann Ent Soc Am 97:1306-1312

Romero-López AA, Morón MA, Valdez J (2010) Sexual dimorphism in antennal receptors of Phyllophaga ravida Blanchard (Coleoptera: Scarabaeoidea: Melolonthidae). Neotrop Entomol 39:957-966

Romero-López AA, Carrillo-Ruiz H, Morón MA (2013) Morphological diversity of antennal sensilla in Hopliinae (Coleoptera: Scarabaeoidea: Melolonthidae). Acad J Entomol 6:20-26

Romero-López AA, Benítez-Herrera LN, Martínez-Bonilla OK, YanesGómez G, Aragón-Sánchez M (2017) Comparative study of distribution of antennal chemoreceptors of Macrodactylus of Mexico. Southwest Entomol 42:111-119

Ryan MF (2002) The chemoreceptive organs: structural aspects. In: Insect chemoreception: fundamental and applied. Springer, Dordrecht, pp 113-139

Scheiner R, Schnitt S, Erber J (2005) The functions of antennal mechanoreceptors and antennal joints in tactile discrimination of the honeybee (Apis mellifera L.). J Comp Physiol A 191:857-864

Schenk O (1902) Die antennalen Hautsinnesorgane einiger Lepidopteren und Hymenopteren mit besonderer Berücksichtigung der sexuellen Unterschiede. Zool Jahrb allg Zool 17:1-47

Schneider D (1964) Insect antennae. Annu Rev Entomol 9:103-122

Scholtz CH, Grebennikov VV (2005) Scrabaeiformia, pp 345-365. Handbook of zoology, Vol. IV, Arthropoda, part II, Insecta (edited by N.P. Kristensen and R.G. Beutel), Coleoptera, Vol. 1:
Morphology and systematics (Archostemata, Adephaga, Myxophaga, Polyphaga partim) (edited by R.G. Beutel and R.A.B. Leschen). Walter De Gruyter, Berlin

Seada MA, Hamza AM (2018) Differential morphology of the sensory sensilla of antennae, palpi, foretarsi and ovipositor of adult Tribolium castaneum (Herbst) (Coleoptera: Tenebrionidae). Ann Agr Sci 63(1):1-8

Shao K-M, Sun Y, Wang W-K, Chen L (2019) A SEM study of antennal sensilla in Maladera orientalis Motschulsky (Coleoptera: Scarabaeidae: Melolonthinae). Micron 119:17-23

Slifer EH, Sekhon SS (1964) Fine structure of the thin-walled sensory pegs on the antenna of a beetle, Popilius disjunctus (Coleoptera; Passalidae). Ann Entomol Soc Am 57:541-548

Snodgrass RE (1926) The morphology of insect sense organs and the sensory nervous system. Smiths Misc Coll 77(8):1-84

Sreedevi K, Kumar PV (2018) Sexual dimorphism in antennal sensilla of Lepidiota mansueta (Burmeister) (Coleoptera: Scarabaeidae: Melolonthinae). J Appl Zool Res 29:23-29

Sun H, Guan L, Feng H, Yin J, Cao Y, Xi J, Li K (2014) Functional characterization of chemosensory proteins in the scarab beetle, Holotrichia oblita Faldermann (Coleoptera: Scarabaeidae). PLoS ONE 8:e107059

Tanaka S, Yukuhiro F, Wakamura S (2006) Sexual dimorphism in body dimensions and antennal sensilla in the white grub beetle, Dasylepida ishigakiensis (Coleoptera: Scarabaeidae). Appl Entomol Zool 41:455-461

Yao Y, Yuan G, Luo M (2004) Observation on the Ultrastructures of antennal sensilla in Anomala corpulenta Motschulsky. Act Agricult Bor-Sin 19:96-99

Zacharuk RY (1980) Ultrastructure and function of insect chemosensilla. Annu Rev Entomol 25:27-47

Zacharuk RY (1985) Antennae and sensilla. In: Keirut GA, Gilbert LI (eds) Comparative insect physiology, biochemistry and pharmacology, vol 6. Pergamon Press, Oxford, pp 1-69

Zauli A, Maurizi E, Carpaneto GM, Chiari S, Svensson GP, Di Giulio A (2016a) Antennal fine morphology of the threatened beetle Osmoderma eremita (Coleoptera: Scarabaeidae), revealed by scanning electron microscopy. Microsc Res Technol 79:178-191

Zauli A, Maurizi E, Carpaneto GM, Chiari S, Merivee E, Svensson GP, Di Giulio A (2016b) Scanning electron microscopy analysis of the antennal sensilla in the rare saproxylic beetle Elater ferrugineus (Coleoptera: Elateridae). Ital J Zool 83:338-350

Publisher's Note Springer Nature remains neutral with regard to jurisdictional claims in published maps and institutional affiliations. 